\title{
Current Insights into Potential Effects of Micro-Nanoplastics on Human Health by in-vitro Tests
}

\author{
Marta Llorca * and Marinella Farré * \\ Department of Environmental Chemistry, IDAEA-CSIC, Barcelona, Spain
}

Humans are exposed to micro and nanoplastics (MNPLs) through inhalation, ingestion and, to a lesser extent, dermal contact. In recent years, new insights indicate the potential of MNPLs to cause damages to human health. Particle toxicity can include oxidative stress, inflammatory lesions, and then increased internalization or translocation through tissues. On the other hand, plastic additives are used in plastic particles, once internalized, can release toxic substances. It is noteworthy that the potential effects of MNPLs encompass a wide range of polymers and chemical additives, showing various physicochemical and toxicological properties, and the size, shape and surface properties are other variables

OPEN ACCESS

Edited by:

Nan Sang,

Shanxi University, China

Reviewed by:

Luciana Dini,

Sapienza University of Rome, Italy Lang Tran,

Institute of Occupational Medicine, United Kingdom

*Correspondence: Marta Llorca mlcqam@cid.csic.es

Marinella Farré

mfuqam@cid.csic.es

Specialty section:

This article was submitted to

Nanotoxicology,

a section of the journal

Frontiers in Toxicology

Received: 02 August 2021 Accepted: 13 September 2021 Published: 29 September 2021

Citation: Llorca M and Farré M (2021) Current Insights into Potential Effects of MicroNanoplastics on Human Health by in-

vitro Tests.

Front. Toxicology. 3:752140. doi: 10.3389/ftox.2021.752140 influencing their effects. In spite of the research carried out recently, MNPLs research is in its early stages, and further investigation is required. In this review article, the knowledge of human exposure routes and the recent results on the toxicological effects of MNPLs in human health are presented and discussed. Finally, the current limitations and the main gaps in the body of knowledge are summarised.

\section{Keywords: nanoplastics, microplastics, human heath, toxicology, routes of exposure}

\section{INTRODUCTION}

Fossil-based plastics have been one of the most impressive revolutions of the last century, contributing to improving the quality of life of humans. Nowadays, plastics are used in all of the industrial sectors because there is a wide variety of available versatile materials. They are inexpensive, strong, durable, lightweight, resistant to degradation, and present thermal and electrical insulation properties (Andrady and Neal, 2009). For that reason, the global production reached 368 million tonnes in 2019 (Plastics the Facts, 2019), and this trend is expected to continue in the coming years. However, as a consequence of incidental events and mismanaged wastes, plastic residues of different sizes can reach the environment and as a conseuence they are currently ubiquitous contaminants. While the problems caused by microplastics (MPLs) in the environment (EerkesMedrano et al., 2015; Horton et al., 2017), and in particular in marine ecosystems (Cole et al., 2011; Ivar Do Sul and Costa, 2014; Llorca et al., 2020a), is a well recognised problem, more recently there is increasing concern regarding the potential for human exposure to MPLs (Wright and Kelly, 2017). Due to the use of items made of plastic and the indirect impact of plastic pollution, humans are constantly exposed to micro- and nanoplastics (MNPLs) through the inhalation of fibres from clothing and fabrics, tyre dust from motor vehicles, ingestion of water with residues (from filters, pipes, and bottles), ingestion of contaminated foods, among many other routes of exposure (Prata et al., 2020).

MPLs have been defined as plastic pieces with a size below $5 \mathrm{~mm}$ (Besseling et al., 2013), including plastic particles at the nano range, known as nanoplastics (NPLs) (Bouwmeester et al., 2015). MPLs 
can have their origin in cosmetics and cleansing products, cloth fibres and vehicle tyre erosion (classified as primary MPLs), and the environmental fragmentation and erosion of plastic pieces and debris (classified as secondary MPLs) (Andrady, 2011). It is important to highlight that the toxicological impact of plastic pollution is partially influenced by the size and shape of the particles (Hwang et al., 2020), as is the case with other nanomaterials (Bouwmeester et al., 2015), as they have much smaller particles and greater ability to be internalised and translocated through tissues in living organisms. As a consequence, their potential toxicity also increases. Nothwithstanding, the smaller the particles, the greater their active surface area, hence they facilitate the leaching of plastic additives, which are chemical ingredients that are added to polymers to enhance their performance and characteristics, but they are not chemically bound to the polymeric chain. Therefore, they can easily leach from plastic particles being another route of exposure to these chemicals in addition to others. Moreover, some plastic additives have already been shown to have toxicological properties that are harmful to the environment and human health (Hermabessiere et al., 2017). On the other hand, the nature of the most used polymers facilitates that once in the environment MNPLs can adsorb and facilitate the transport of other environmental contaminants (Llorca et al., 2018; Llorca et al., 2020a) and pathogens to living organisms, which is known as the Trojan horse effect. This ability to adsorb and desorb other contaminants and pathogens is not only dependent on the polymeric composition of the particle, but is also size dependent because, again, the smaller the particles, the greater their active surface area.

However, to the best of our knowledge, to date the consequences of MNPL exposure on human health are not well understood. In addition, the extensive number of polymers and plastic additives that are involved, with variables such as the size and shape of the particles, and the current analytical limitations, should also be considered.

Under this frame this paper has been organised into the following sections: 1) main human routes of exposure; 2) pathways of particle toxicity; 3 ) toxicity of plastic additives on human health; 4) insights about Trojan horse effects on human health; and 5) future reaserch trends.

\section{MAIN ROUTES OF HUMAN EXPOSURE}

Recent studies indicate that MNPLs are present in most classes of consumer products. In foodstuffs, MNPLs can be present in animals which are contaminated through their environment or food chains, as happens with seafood (Santillo et al., 2017) for example, and also they can be contaminated during their production processes or packaging (Lau and Wong, 2000; Mason et al., 2018; Du et al., 2020). In the case of drinking water, MPL contamination can come from pipes, filters, or bottles (Oßmann, 2021). In addition to a portion of MNPLs that we can ingest incidentally, such as the MPLs that are present in some toothpaste formulas. Also, dust from plastics, car tyres, paints, and textile fibres are sources of MNPLs in the Earth's atmosphere and can be inhaled or can undergo dermal interaction with humans. Moreover, MPLs are used in the formula of certain personal care products (PCPs) (Laborda et al., 2021), implying dermal interaction. Therefore, the main routes of human exposure to MNPLs are ingestion, inhalation, and dermal contact (Figure 1). However, the total contribution of MNPLs to exogenous particles exposure is still unknown, and due to their unique composition and properties, the human biological responses will differ from those of other exogenous materials.

Ingestion is considered as the major route of human exposure to MNPLs (Galloway, 2015), and the tissues of the human gastrointestinal tract (GIT) are considered among the most exposed. In particular, the Peyer's patches of the ileum in the small intestine have potentially been defined as the main sites of uptake and translocation of anthropogenic particles. The Peyer's patches are part of the gut-associated lymphoid tissues (Powell et al., 2010). The $M$ cells of these patches can transport particles $(0.1-10 \mu \mathrm{m})$ from the intestine to the mucosal lymphoid tissues, responsible for initiating immune responses to specific antigens that are encountered along all mucosal surfaces. The subepithelial area of the Peyer's patches can store non-degradable particles, and consequently they disrupt the immunity processes (Campanale et al., 2020). For bigger particles, up to $130 \mu \mathrm{m}$ diameter, persorption performed by GIT epithelial cells is another route of uptake but not of adsorption and is the cellular passage of large particles through the epithelial layer of the GIT. In addition to particle size, other factors that can influence the uptake and translocation of MNPLs are their chemical composition, shape, and hydrophobicity. Hydrophobic surfaces can be better transported through the mucus layer. Moreover, these characteristics also influence the adsorption of proteins and other biomolecules to the particle surface, known as corona formation (Lunov et al., 2011). Therefore, the surface charge of MNPLs can also influence the extent and pathway of translocation to other organs. Food and drinking water are key factors in the assessment of human MNPL exposure through ingestion, but most of the studies till now have been focused on fish and seafood, rather than on other foodstuffs.

MPLs in molluscs, such as mussels (Van Cauwenberghe and Janssen, 2014; Li et al., 2015; Smith et al., 2018), have been widely studied because they are living in intertidal areas, where the abundance of MPLs is expected to be higher due to the density of the polymers. For that reason, mussels are particularly exposed (Coppola et al., 2020). Moreover, the edible part of molluscs includes the stomach, intestine and digestive glandular, and they are consumed worldwide, thus potentially representing a source of MPLs in the human diet. As shown in Table 1, the concentrations of MPLs in molluscs present a high variability, for example, ranging from 0.05 to 3 MPLs items per $g$ wet weight (ww) of edible tissue in mussels. This variability among molluscs is highly influenced by the habitat between different species and, in particular, the degree of contamination of the different sampled areas, in addition of the diversity of analytical methods used, including the diversity of the sample preparation approaches. Karlsson et al. (Karlsson et al., 2017) studied the accumulation of MPLs in mussels and the surrounding water and sediments, and their findings indicated 
TABLE 1 | Summary of studies assessing MNPLs in foodstuffs.

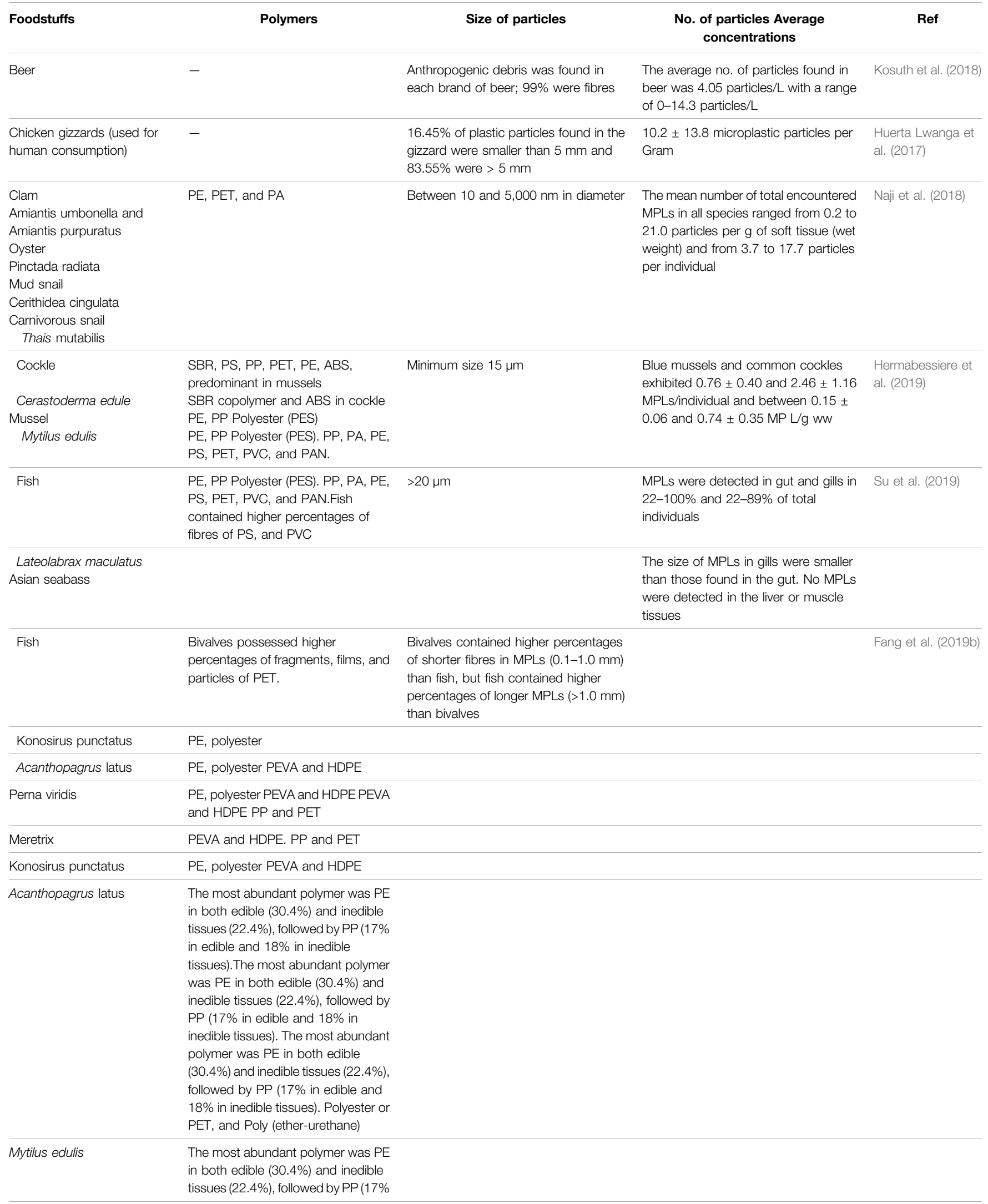


TABLE 1 | (Continued) Summary of studies assessing MNPLs in foodstuffs.

Foodstuffs
Polymers
Size of particles
No. of particles Average concentrations
Ref

in edible and $18 \%$ in inedible tissues). The most abundant polymer was PE in both edible (30.4\%) and inedible tissues (22.4\%), followed by PP (17\% in edible and $18 \%$ in inedible tissues). The most abundant polymer was PE in both edible (30.4\%) and inedible tissues (22.4\%), followed by PP (17\% in edible and $18 \%$ in inedible tissues). Polyester or PET, and Poly (etherurethane). PEVA and HDPE. PP and PET.

Meretrix The most abundant polymer was PE in both edible $(30.4 \%)$ and inedible tissues (22.4\%), followed by PP (17\% in edible and $18 \%$ in inedible tissues). The most abundant polymer was PE in both edible (30.4\%) and inedible tissues (22.4\%), followed by PP (17\% in edible and $18 \%$ in inedible tissues). The most abundant polymer was PE in both edible (30.4\%) and inedible tissues (22.4\%), followed by PP (17\% in edible and $18 \%$ in inedible tissues). Polyester or PET, and Poly (etherurethane)

Fish; 3 species $\quad$ The most abundant polymer was PE in both edible (30.4\%) and inedible tissues $(22.4 \%)$, followed by PP (17\% in edible and $18 \%$ in inedible tissues). The most abundant polymer was PE in both edible (30.4\%) and inedible tissues (22.4\%), followed by PP (17\% in edible and $18 \%$ in inedible tissues). The most abundant polymer was PE in both edible (30.4\%) and inedible tissues (22.4\%), followed by PP (17\% in edible and $18 \%$ in inedible tissues). Polyester or PET, and Poly (etherurethane) PEVA and HDPE PP and PET. PEVA and HDPE PP and PET. The most abundant polymer was $\mathrm{PE}$ in both edible (30.4\%) and inedible tissues (22.4\%), followed by PP (17\% in edible and $18 \%$ in inedible tissues).

\begin{abstract}
Dicentrachus labrax
\end{abstract}
$0.4 \pm 0.7$ MPLs items/g; $0.7 \pm$ 1.3 MPLs items/g; and 0.6 \pm 0.8 MPLs (2020) items $/ g$ in the dorsal muscle of $D$. labrax, T. trachurus and S. colias, respectively
The total mean $( \pm S D)$ of the number of MPLs in the dorsal muscle was $0.054 \pm$ 0.099 items $/ \mathrm{g}$

\section{Trachurus}

Scomber colias

The most abundant polymer was PE in both edible (30.4\%) and inedible tissues (22.4\%), followed by PP (17\% in edible and $18 \%$ in inedible tissues). The most abundant polymer was PE in both edible (30.4\%) and inedible tissues $(22.4 \%)$, followed by PP (17\% in edible and $18 \%$ in inedible tissues). Polyester or PET, and Poly (etherurethane). Polyester or PET, and Poly
Average concentrations in edible parts Zitouni et al. (2020) $0.2 \pm 0.3$ particles $/ g$ tissue.

(Continued on following page) 
TABLE 1 | (Continued) Summary of studies assessing MNPLs in foodstuffs.

\begin{tabular}{|c|c|c|c|c|}
\hline Foodstuffs & Polymers & Size of particles & $\begin{array}{l}\text { No. of particles Average } \\
\text { concentrations }\end{array}$ & Ref \\
\hline & $\begin{array}{l}\text { (ether-urethane) Polyester or PET, } \\
\text { and Poly (ether-urethane) }\end{array}$ & & & \\
\hline \multicolumn{5}{|l|}{$\begin{array}{l}\text { Serranus scriba - lettered } \\
\text { perch }\end{array}$} \\
\hline $\begin{array}{l}\text { Fish; canned sardines and } \\
\text { sprats originating from } 13 \\
\text { countries }\end{array}$ & $\begin{array}{l}\text { The most abundant polymer was PE } \\
\text { in both edible ( } 30.4 \% \text { ) and inedible } \\
\text { tissues ( } 22.4 \%) \text {, followed by PP ( } 17 \% \\
\text { in edible and } 18 \% \text { in inedible tissues). } \\
\text { Polyester or PET, and Poly (ether- } \\
\text { urethane). Polyester or PET, and Poly } \\
\text { (ether-urethane). Polyester or PET, } \\
\text { and Poly (ether-urethane). Polyester } \\
\text { or PET, and Poly (ether-urethane). } \\
\text { Polyester or PET, and Poly (ether- } \\
\text { urethane)Polyester or PET, and Poly } \\
\text { (ether-urethane). PU, PVCA, PVC, } \\
\text { PES, PVC/Acrylic alloy, PET, PVK, } \\
\text { PEVA. }\end{array}$ & $>149 \mu \mathrm{m}$ & 1 and 3 plastic particles & Karami et al. (2018) \\
\hline Fish, crab, and prawn & $\begin{array}{l}\text { The most abundant polymer was PE } \\
\text { in both edible ( } 30.4 \% \text { ) and inedible } \\
\text { tissues ( } 22.4 \%) \text {, followed by PP ( } 17 \% \\
\text { in edible and } 18 \% \text { in inedible tissues). } \\
\text { Polyester or PET, and Poly (ether- } \\
\text { urethane) olyester or PET, and Poly } \\
\text { (ether-urethane) Polyester or PET, } \\
\text { and Poly (ether-urethane) }\end{array}$ & & $\begin{array}{l}\text { Penaeus semisulcatus and } \\
\text { Epinephelus coioides displayed the } \\
\text { highest (mean } 0.360 \text { items } / g \text { muscle) } \\
\text { and lowest (mean } 0.158 \text { items } / g \\
\text { muscle) }\end{array}$ & $\begin{array}{l}\text { Akhbarizadeh et al. } \\
\text { (2019) }\end{array}$ \\
\hline $\begin{array}{l}\text { Fish pelagic species: } \\
\text { Rastrelliger kanagurta, }\end{array}$ & $\begin{array}{l}\text { The most abundant polymer was PE } \\
\text { in both edible }(30.4 \%) \text { and inedible }\end{array}$ & $<100 \mu \mathrm{m}$ & $\begin{array}{l}0.07 \pm 0.26 \text { items per fish in edible } \\
\text { tissues }\end{array}$ & Daniel et al. (2020) \\
\hline
\end{tabular}

Megalaspis cordyla tissues (22.4\%), followed by PP (17\%

in edible and $18 \%$ in inedible tissues). Polyester or PET, and Poly (etherurethane). Polyester or PET, and Poly (ether-urethane). Polyester or PET, and Poly (ether-urethane) Polyester or PET, and Poly (ether-urethane) Polyester or PET, and Poly (etherurethane) Polyester or PET, and Poly (ether-urethane) PU, PVCA, PVC, PES, PVC/Acrylic alloy, PET, PVK, PEVA. Polyester or PET, and Poly (ether-urethane) Polyester or PET, and Poly (ether-urethane) Polyester or PET, and Poly (ether-urethane) PU, PVCA, PVC, PES, PVC/Acrylic alloy, PET, PVK, PEVA. PU, PVCA, PVC, PES, PVC/Acrylic alloy, PET, PVK, PEVA. PU, PVCA, PVC, PES, PVC/Acrylic alloy, PET, PVK, PEVA. Eighteen types of polymers detectedPU, PVCA, PVC, PES, PVC/ Acrylic alloy, PET, PVK, PEVA. Eighteen types of polymers detected PVC and rayon being the most abundant types

Sardinella longiceps

Sardinella gibbosa

Stolephorus indicus,

Dussumieria acuta

Thryssa dussumieri 
TABLE 1 | (Continued) Summary of studies assessing MNPLs in foodstuffs.

Foodstuffs
Polymers
Size of particles
No. of particles Average concentrations

Sphyraena obtusata and

$\begin{array}{ll}\text { Anodontostoma chacunda } & \\ \text { Fruit } & \text { Polyester or PET, and Poly (ether- } \\ \text { urethane) Polyester or PET, and Poly } & \text { (ether-urethane) Polyester or PET, } \\ & \text { and Poly (ether-urethane) PU, PVCA, } \\ & \text { PVC, PES, PVC/Acrylic alloy, PET, } \\ & \text { PVK, PEVAPU, PVCA, PVC, PES, } \\ & \text { PVC/Acrylic alloy, PET, PVK, PEVA. } \\ & \text { PU, PVCA, PVC, PES, PVC/Acrylic } \\ & \text { alloy, PET, PVK, PEVA. Eighteen } \\ & \text { types of polymers detected. PU, } \\ & \text { PVCA, PVC, PES, PVC/Acrylic alloy, } \\ & \text { PET, PVK, PEVA. Eighteen types of } \\ & \text { polymers detected. PVC and rayon } \\ & \text { being the most abundant types -PU, } \\ & \text { PVCA, PVC, PES, PVC/Acrylic alloy, } \\ & \text { PET, PVK, PEVA. PU, PVCA, PVC, } \\ & \text { PES, PVC/Acrylic alloy, PET, PVK, } \\ & \text { PEVA. Eighteen types of polymers } \\ & \text { detected. PU, PVCA, PVC, PES, } \\ & \text { PVC/Acrylic alloy, PET, PVK, PEVA. } \\ & \text { Eighteen types of polymers detected. } \\ & \text { PVC and rayon being the most } \\ \text { abundant types PU, PVCA, PVC, } & \text { PES, PVC/Acrylic alloy, PET, PVK, } \\ & \text { PEVA. }\end{array}$

Malus domestica - apple
Pyrus communis - pear
Vegetables

In $P$. communis median size $1.99 \mu \mathrm{m}$

In B. oleracea italica Domestica median size $2.10 \mu \mathrm{m}$

In L. Sativa median size $2.52 \mu \mathrm{m}$

B. oleracea italic- broccoli

In $D$. Carota median size $1.51 \mu \mathrm{m}$

Lactuca sativa - lettuce

$20 \mu \mathrm{m}$

Daucus carota - carrots

Solanum tuberosum potato

\section{Mussel species}

PU, PVCA, PVC, PES, PVC/Acrylic alloy, PET, PVK, PEVA.PU, PVCA PVC, PES, PVC/Acrylic alloy, PET, PVK, PEVA. Eighteen types of polymers detected PU, PVCA, PVC, PES, PVC/Acrylic alloy, PET, PVK, PEVA. Eighteen types of polymers detected. PVC and rayon being the most abundant types. PU, PVCA, PVC, PES, PVC/Acrylic alloy, PET, PVK, PEVA. PU, PVCA, PVC, PES, PVC/Acrylic alloy, PET, PVK, PEVA.

\author{
In M. Domestica median size $2.17 \mu \mathrm{m}$ \\ MNPs particles in M. Domestica \\ (Oliveri Conti et al., \\ 195,500 , in P. Communis 189,550, in 2020) \\ B. oleracea italica 126,150, in L. Sativa \\ 50,550, and in D. Carota 101,950
}

Ref
$20 \mu \mathrm{m}$. MPL length ranged from 30 to $2000 \mu \mathrm{m}$ with a median length of $200 \mu \mathrm{m}$

\section{$20 \mu \mathrm{m}$. MPL length ranged from 30 to} $2000 \mu \mathrm{m}$ with a median length of $200 \mu \mathrm{m} 61.02$ and $77.42 \%$ of the particles belonged to the size group of $<100 \mu \mathrm{m}$ in M. meretrix and P. viridis, respectively
In these mussels, the mean load of observed particles was $3 \pm 0.9$ particles/g ww, equivalent to $3.2 \pm 0.52$ particles per mussel. In M. modiolus the concentration of MPLs were substantially heavier, $42.91 \pm$ $2.111 \mathrm{~g}$
Catarino et al. (2018)

\section{Mytilus edulis}

Mytilus spp. and the subtidal

\begin{tabular}{ll}
\multicolumn{1}{l}{ Modiolus } \\
Mussel & PP, PA, PAN, PE, PEVA, CP. PP, PA, \\
& PAN, PE, PEVA, CP. Several but PE \\
& being the predominant
\end{tabular}

61.02 and $77.42 \%$ of the particles belonged to the size group of $<100 \mu \mathrm{m}$ in $M$. meretrix and $P$. viridis, respectivelyMPL length ranged from 30

$\begin{array}{ll}\text { Average concentration } 0.2 \pm & \text { Van } \\ 0.3 \text { particle/g tissue } & \text { Cauwenberghe et } \\ & \text { al. (2015) }\end{array}$

(Continued on following page) 
TABLE 1 | (Continued) Summary of studies assessing MNPLs in foodstuffs.

Foodstuffs
Polymers
Size of particles
No. of particles Average concentrations
Ref

to $2000 \mu \mathrm{m}$ with a median length of

$200 \mu \mathrm{m}$

$\begin{array}{ll}\text { Mytilus edulis } & \\ \text { Mussel } & \text { PP, PA, PAN, PE, PEVA, CP. PP, PA, } \\ & \text { PAN, PE, PEVA, CP. Several but PE } \\ \text { being the predominant. PP, PA, } & \text { PAN, PE, PEVA, CP. Several but PE } \\ & \text { being the predominant Several but } \\ & \text { PE being the predominant. PE } \\ \text { Mytilus edulis } & \\ \text { Mussel } & \text { PP, PA, PAN, PE, PEVA, CP. PP, PA, } \\ & \text { PAN, PE, PEVA, CP Several but PE } \\ & \text { being the predominant. PP, PA, } \\ & \text { PAN, PE, PEVA, CP. Several but PE } \\ & \text { being the predominant. Several but } \\ & \text { PE being the predominant. PE. } \\ & \text { Several but PE being the } \\ & \text { predominant. PE }\end{array}$

Perna viridis

MPL length ranged from 30 to $2000 \mu \mathrm{m}$

with a median length of $200 \mu \mathrm{m}$.

Average amount: 37,000 ( $\sigma=25,000)$

Microfibre was the most predominant

microplastics $\mathrm{kg} / \mathrm{dw}$

Karlsson et al.

shape with diameters between 7 and

$5,000 \mu \mathrm{m}$

Microfibre was the most predominant shape with diameters between 7 and 5,000 $\mu \mathrm{m}$ Microfibre was the most predominant shape with diameters between 7 and 5,000 $\mu \mathrm{m}$. Particle size varied from 36 to $4,439 \mu \mathrm{m}$, being fibers the most abundant shape (50\%) followed by films (22\%). 150-6,000 $\mu \mathrm{m}$

$\begin{array}{ll}\text { Average abundance } & \text { Dowarah et al. } \\ \text { (2020) }\end{array}$

Dowarah et al

(1)
$0.18 \pm 0.04 \mathrm{~g}$ tissue $w w, 1.84 \pm 0.61 \mathrm{~g}$ tissue ww and $1.76 \pm 0.48 \mathrm{~g}$ tissue $\mathrm{ww}$; and the number of MPLs per bivalve is $0.50 \pm 0.11,1.75 \pm 0.35$, and $4.80 \pm$ 1.39 , respectively, for the 3 locations sampled: Ariyankuppam, Panithittu, and Chunnambar

\begin{tabular}{|c|c|c|}
\hline \multicolumn{3}{|c|}{ Meretrix } \\
\hline Mussel & PE. CP, PE and PET & $\begin{array}{l}\text { Microfibre was the most predominant } \\
\text { shape with diameters between } 7 \text { and } \\
5,000 \mu \mathrm{m} \text {. Particle size varied from } 36 \text { to } \\
4,439 \mu \mathrm{m} \text {, being fibers the most } \\
\text { abundant shape ( } 50 \% \text { ) followed by films } \\
(22 \%) .150-6,000 \mu \mathrm{m} \text {. Particle size } \\
\text { varied from } 36 \text { to } 4,439 \mu \mathrm{m} \text {, being fibers } \\
\text { the most abundant shape (50\%) } \\
\text { followed by films ( } 22 \%) .150-6,000 \mu \mathrm{m}\end{array}$ \\
\hline
\end{tabular}

\begin{tabular}{|c|c|c|c|c|}
\hline $\begin{array}{l}\text { Mytilus galloprovincialis, } \\
\text { oyster }\end{array}$ & $\begin{array}{l}\text { PP, PA, PAN, PE, PEVA, CP. Several } \\
\text { but PE being the predominant }\end{array}$ & & $\begin{array}{l}\text { Detected in the } 80 \% \text { of the samples } \\
\text { over four seasons }\end{array}$ & \\
\hline Crassostrea gigas, clam & $\begin{array}{l}\mathrm{CP}, \mathrm{PE} \text { and PET. CP, PE and PET. } \\
\mathrm{PET} \text {, polyester, and PA, cellulose } \\
\text { acetate and } \mathrm{CP}\end{array}$ & & & \\
\hline Ruditapes philippinarum & $\begin{array}{l}\text { CP, PE and PET. CP, PE and PET. } \\
\text { PET, polyester, and PA, cellulose } \\
\text { acetate and CP. Several but PE } \\
\text { being the predominant. PE. CP, PE } \\
\text { and PET, polyester, and PA, cellulose } \\
\text { acetate and CP PET, polyester, and } \\
\text { PA, cellulose acetate and CPXPS }\end{array}$ & & & \\
\hline Scallop & $\begin{array}{l}\mathrm{CP}, \mathrm{PE} \text { and } \mathrm{PET} \text {, polyester, and PA, } \\
\text { cellulose acetate and } \mathrm{CP}\end{array}$ & & & \\
\hline Chlamys farreri & $\begin{array}{l}\text { Several but PE being the } \\
\text { predominant PE. CP, PE and PET. } \\
\text { PET, polyester, and PA, cellulose } \\
\text { acetate and CP. PET, polyester, and } \\
\text { PA, cellulose acetate and CP XPS PE } \\
\text { CP, PE and PET }\end{array}$ & & & \\
\hline Mussel & $\begin{array}{l}\text { Several but PE being the } \\
\text { predominant PE CP, PE and PET }\end{array}$ & $\begin{array}{l}\text { Particle size varied from } 36 \text { to } 4,439 \mu \mathrm{m} \text {, } \\
\text { being fibers the most abundant shape }\end{array}$ & & $\begin{array}{l}\text { Marques et al. } \\
\text { (2021) }\end{array}$ \\
\hline
\end{tabular}

Average ranging from 0.5 to 3.3 items/ Ding et al. (2021) individual

(Continued on following page) 
TABLE 1 | (Continued) Summary of studies assessing MNPLs in foodstuffs.

Foodstuffs
Polymers

PET, polyester, and PA, cellulose acetate and CP PET, polyester, and PA, cellulose acetate and CP XPS PE $\mathrm{CP}, \mathrm{PE}$ and PET PE CP, PE and PET, polyester, and PA, cellulose acetate and CP XPS

Mytilus spp.

Mussel PE CP, PE and PET PET, polyester, and $\mathrm{PA}$, cellulose acetate and $\mathrm{CP}$ XPS PET, polyester, and PA, cellulose acetate and CP XPS polyesters, PET, PA, PE, PS polyesters, PET, PA, PE, PS PE, PP, PS

Mytilus galloprovincialis

Mussel (processed)

PET, polyester, and PA, cellulose Oysters $8.30 \pm 0.45$. Mussels $1.24 \pm$ acetate and CP XPS polyesters, PET, PA, PE, PS. polyesters, PET, PA, PE, PS PE, PP, PS. PET, polyester, and PA, cellulose acetate and CP XPS. polyesters, PET, PA, PE, PS polyesters, PET, PA, PE, PS. PE, PP, PS. polyesters, PET, PA, PE, PS. polyesters, PET, PA, PE, PS. PE, PP, PS. PP, PE, PA and cellulose

\subsection{4 . Fibres were the most common}

shape $(60.67 \%)$, and the most common
No. of particles Average concentrations

MPLs concentrations ranged from 0.54

to 3.0 items $/ \mathrm{g}$ without significant

differences among the sites
Ref
(50\%) followed by films (22\%)

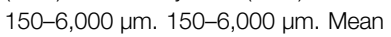
length $\pm \mathrm{SD}(\mathrm{cm})$
Size of particles

150-6,000 $\mu \mathrm{m}$ Mean length \pm SD $(\mathrm{cm})$ Oysters $8.30 \pm 0.45$. Mussels 1.24 $\pm 0.14$
$0.20 \pm 0.24$ items $/ g$ ww; $0.40 \pm 0.47 \quad$ Nalbone et al. items/individual

$0.9 \pm 0.10 \mathrm{items} / \mathrm{g}$ ww: $0.17 \pm 0.19$

Nalbone et al. items/individual

Mytilus galloprovincialis

\section{Mussel and oyster}

PET, polyester, and PA, cellulose acetate and CP XPS. polyesters, PET, PA, PE, PS. polyesters, PET, PA, PE, PS. PE, PP, PS. polyesters, PET, PA, PE, PS polyesters, PET, PA, PE, PS PE, PP, PS PP, PE, PA and cellulose polyesters, PET, PA, PE, PS polyesters, PET, PA, PE, PS PE, PP, PS PP, PE, PA and cellulose PP, PE, PA and cellulose Polyester, PVC, PA, PE

Mytilus galloprovincialis

Crassostrea gigas

\section{Mussels $1.24 \pm 0.14$}

Over $99 \%$ of suspected MPLs encountered were microfibres with an average length of $1.33 \pm 0.04 \mathrm{~mm}$ (range $=0.11-7.84 \mathrm{~mm}$ ) 4.0 to 18.7 MP-XPS/kg of packaged meat

\section{Oyster}

polyesters, PET, PA, PE, PS polyesters, PET, PA, PE, PS PE, PP, PS PP, PE, PA and cellulose PP, PE, PA and cellulose Polyester, PVC, PA, PE, PE, PP, PPS, PS. PET, PPT, epoxy resin, Rayon, PET, PE, PS,Polyester, PAA, PMPS, PI
Over $99 \%$ of suspected MPLs encountered were microfibres with an average length of $1.33 \pm 0.04 \mathrm{~mm}$ (range $=0.11-7.84 \mathrm{~mm}$ ) 4.0 to 18.7 MP-XPS/kg of packaged meat $4-2,100 \mu \mathrm{m}$ in Italian salt

\section{$0.11 \mathrm{MPLs} / \mathrm{g}$}

Mytilus galloprovincialis $0.05 \mathrm{MP} \mathrm{L} / \mathrm{g}$

Average abundance of MPLs in oyster was 0.62 items/g ww or 2.93 items/ individual

Crassostrea gigas

Crassostrea angulate, Crassostrea hongkongensis, Crassostrea sikamea

Pacific razor clam

\author{
PE, PP, PPS, PS. PET, PPT, epoxy $\quad 4-2,100 \mu \mathrm{m}$ in Italian salt 15-4,628 $\mu \mathrm{m}$ \\ resin, Rayon, PET, PE, PS, Polyester, in Croatian salt \\ PAA, PMPS, PI, PPT, epoxy resin, \\ Rayon, PET, PE, PS,Polyester, PAA,
}

Average amounts: Crassostrea gigas Bonello et al. (2018) 
TABLE 1 | (Continued) Summary of studies assessing MNPLs in foodstuffs.

Foodstuffs
Polymers
Size of particles
No. of particles Average concentrations

PMPS, PI, PET, PP, PE or

polyoleofins

\begin{tabular}{|c|c|c|c|c|}
\hline \multicolumn{5}{|l|}{ Siliqua patula } \\
\hline Poultry meat (packed) & $\begin{array}{l}\text { PPT, epoxy resin, Rayon, PET, PE, } \\
\text { PS,Polyester, PAA, PMPS, PI }\end{array}$ & $\begin{array}{l}80 \% \text { of the extracted fibres and the } \\
\text { fragments were smaller than } 2000 \text { and } \\
500 \mu \mathrm{m} \text {, respectively }\end{array}$ & 130 and $250 \mu \mathrm{m}$ & $\begin{array}{l}\text { Kedzierski et al. } \\
(2020)\end{array}$ \\
\hline Sea salt & & $\begin{array}{l}\text { The majority were fibres }(98.3 \%) \\
0.1-5 \mathrm{~mm}\end{array}$ & 27.13-31.68 MPLs/g in Croatian salt & \\
\hline Sea salt & PPT, epoxy resin & $\begin{array}{l}42 \% \text { of the samples containing MPLs } \\
\text { fragments }>20 \mu \mathrm{m}\end{array}$ & $\begin{array}{l}\text { particles ranged from } 103 \pm 39 \text { to } 56 \pm \\
49 \mathrm{MPLs} / \mathrm{kg} \text { of salt }\end{array}$ & $\begin{array}{l}\text { Seth and } \\
\text { Shriwastav, (2018) }\end{array}$ \\
\hline Water (Tap-water) & & $\begin{array}{l}100 \% \text { of the samples containing MPLs. } \\
\text { Fibres > fragments }\end{array}$ & Mean value 5.45 particles $/ L$ & Kosuth et al. (2018) \\
\hline Water (Tap-water) & & $\begin{array}{l}\text { Small MPLs }(-50-500 \mu \mathrm{m}) \text { and very } \\
\text { small }(1-50 \mu \mathrm{m}) \text { fragments were found } \\
\text { in every type of water. Almost } 80 \% \text { of all } \\
\text { MNPLs found had a particle size } \\
\text { between } 5 \text { and } 20 \mu \mathrm{m}\end{array}$ & 0-0.0007 MP L/L & $\begin{array}{l}\text { Mintenig et al. } \\
\text { (2019) }\end{array}$ \\
\hline Water (Tap-water) & & & 0-1,247 MPLs/L & Tong et al. (2020) \\
\hline Water (Tap-water) & & $\begin{array}{l}\text { Fragments were the most common } \\
\text { morphology }(66 \%)\end{array}$ & $5 \pm 2$ to $91 \pm 14$ & Shruti et al. (2020b) \\
\hline & & & $\begin{array}{l}\text { Including smaller particles }(6.5-100 \\
\text { um), an average of } 325 \mathrm{MPLs} / \mathrm{L} \text { of } \\
\text { bottled water. MPLs contamination } \\
\text { range of } 0 \text { to over } 10,000 \mathrm{MPLs} / \mathrm{L} \text { with } \\
95 \% \text { of particles being between } 6.5 \\
\text { and } 100 \text { um in size }\end{array}$ & \\
\hline Water (bottled) & & & $\begin{array}{l}\text { Average concentration was } \\
\text { approximately } 8.5 \pm 10.2 \text { particles/L }\end{array}$ & $\begin{array}{l}\text { Makhdoumi et al. } \\
\text { (2021) }\end{array}$ \\
\hline
\end{tabular}

acrylonitrile-butadiene-styrene (ABS); cellophane (CP); high density polyethylene (HDPE); polyamide (PA); polyacrylic acid (PAA); polyacrylonitrile (PAN); polyethylene (PE); poly (pphenylene ether sulfone) (PES); polyethylene terephthalate (PET); polyethylene-vinyl-acetate (PEVA); polyimide (PI); polymethyl pentene (PMPS); Polyester; polypropylene (PP); polyphenylene sulfide (PPS); polystyrene (PS); polyester urethane (PU); polyvinyl chloride (PVC); vinyl chloride/vinyl acetate copolymer (PVCA); poly (N-vinyl carbazole) (PVK); styrene butadiene rubber copolymer (SBR); extruded polystyrene (XPS). 
TABLE 2 | Summary of studies assessing MNPLs in airborne particulate and atmospheric deposition.

\begin{tabular}{|c|c|c|c|c|c|}
\hline Place & Size range & Abundance & Shape & Polymers & Ref \\
\hline \multicolumn{6}{|c|}{ Outdoor } \\
\hline \multirow{6}{*}{$\begin{array}{l}\text { China ( } 21 \text { transects from the } \\
\text { Pearl River Estuary to the South } \\
\text { China Sea and then to the East } \\
\text { Indian Ocean }\end{array}$} & $\begin{array}{l}\text { Pearl River } \\
\text { estuary }\end{array}$ & Pearl River estuary & Pearl River estuary & \multirow[t]{6}{*}{$\begin{array}{l}\text { PET, PP, PA, PEP, } \\
\text { PAN-AA, PR, PEVA }\end{array}$} & \multirow[t]{6}{*}{$\begin{array}{l}\text { Wang et al. } \\
\text { (2020b) }\end{array}$} \\
\hline & $288.2-1,117.62$ & $4.2 \pm 2.5 \mathrm{MPLs} / 100 \mathrm{~m}^{3}$ & Fibres & & \\
\hline & South China Sea & South China Sea & South China Sea & & \\
\hline & $58.591-988.37$ & $0.8 \pm 1.3 \mathrm{MPLs} / 100 \mathrm{~m}^{3}$ & Fibres $80 \%$, fragments $20 \%$ & & \\
\hline & $\begin{array}{l}\text { East Indian } \\
\text { ocean }\end{array}$ & East Indian ocean & East Indian ocean & & \\
\hline & $286.10-1861.78$ & $0.4 \pm 0.6 \mathrm{MPLs} / 100 \mathrm{~m}^{3}$ & Fibres $75 \%$, fragments $25 \%$ & & \\
\hline China (Yantai) & $50-1,000$ & Range: $130-624 \mathrm{MPLs} / \mathrm{m}^{2} / \mathrm{d}$ & Fibres, foam, film, fragments & PET, PVC, PE, PS & $\begin{array}{l}\text { Zhou et al. } \\
\text { (2017) }\end{array}$ \\
\hline France (urban area of Paris) & $50-3,200$ & $\begin{array}{l}\text { Range } \\
2-355 \mathrm{MPLs} / \mathrm{m}^{2} / \mathrm{d} ; \text { average } \\
110 \pm 96 \mathrm{MPLs} / \mathrm{m}^{2} / \mathrm{d}\end{array}$ & Fibres & RY, PET, PU & $\begin{array}{l}\text { Dris et al. } \\
(2016)\end{array}$ \\
\hline France (suburban area of Paris) & $50-3,200$ & $\begin{array}{l}\text { Mean } \\
53 \pm 38 \mathrm{MPLs} / \mathrm{m}^{2} / \mathrm{d}\end{array}$ & Fibres & RY, PET, PU & $\begin{array}{l}\text { Dris et al. } \\
(2016)\end{array}$ \\
\hline France (Paris) & $59-1650 \mu$ & $\begin{array}{l}\text { Range } \\
0.3-1.5 \mathrm{MPLs} / \mathrm{m}^{3} \text { average } \\
0.9 \mathrm{MPLs} / \mathrm{m}^{3}\end{array}$ & Fibres & -- & $\begin{array}{l}\text { Dris et al. } \\
(2017)\end{array}$ \\
\hline $\begin{array}{l}\text { France (Pyrenees; mountain } \\
\text { range) }\end{array}$ & $50-700$ & $\begin{array}{l}\text { Average } \\
365 \pm 69 \mathrm{MPLs} / \mathrm{m}^{2} / \mathrm{d}\end{array}$ & Fibres & PS, PE, PP, PVC, PET & $\begin{array}{l}\text { Allen et al. } \\
\text { (2019) }\end{array}$ \\
\hline $\begin{array}{l}\text { Iran (Asaluyeh - County-urban } \\
\text { area) }\end{array}$ & $2-5,000$ & $\begin{array}{l}\text { Average } \\
0.63 \mathrm{MPLs} / \mathrm{m}^{3}\end{array}$ & Fibres & -- & $\begin{array}{l}\text { Abbasi et al. } \\
\text { (2019) }\end{array}$ \\
\hline $\begin{array}{l}\text { New Zealand (Christchurch- } \\
\text { Suburban area) }\end{array}$ & & & Fibres & & $\begin{array}{l}\text { Knobloch } \\
\text { et al. (2021) }\end{array}$ \\
\hline West Pacific Ocean & $20-2000$ & $\begin{array}{l}\text { Coastal area }\left(0.13 \pm 0.24 \mathrm{MPLs} / \mathrm{m}^{3}\right) \\
\text { Pelagic area }\left(0.01 \pm 0.01 \mathrm{MPLs} / \mathrm{m}^{3}\right) \\
\text { Daytime }\left(0.45 \pm 0.46 \mathrm{MPLs} / \mathrm{m}^{3}\right) \text { was } \\
\text { twice the amount collected at night } \\
\left(0.22 \pm 0.19 \mathrm{MPLs} / \mathrm{m}^{3}\right) \text {, on average }\end{array}$ & $\begin{array}{l}\text { Fibres, fragment, and granule } \\
\text { quantitatively constituted } 60 \text {, } \\
31 \text {, and } 8 \% \text { of all MPLs, } \\
\text { respectively }\end{array}$ & $\begin{array}{l}\text { PET, EP, PE-PP, PS, } \\
\text { PE, PVC, Phe, ALK, } \\
\text { PMA, PA, PVA, } \\
\text { PAN, PP }\end{array}$ & $\begin{array}{l}\text { Liu et al. } \\
\text { (2019b) }\end{array}$ \\
\hline \multicolumn{6}{|c|}{ Indoor } \\
\hline France (Paris) & $50-5,000$ & $\begin{array}{l}\text { Average 190-670 } \\
\text { MPLs/mg }\end{array}$ & Fibres & --- & $\begin{array}{l}\text { Dris et al. } \\
(2017)\end{array}$ \\
\hline China & $50-2000$ & $\begin{array}{l}\text { Range of fibres: } 17-620 \text { fibres/mg, } \\
\text { mean of fibres: } 342 \text { fibres/mg; range } \\
\text { of granules: } 6-184 \text { particles/mg }\end{array}$ & Fibres, granule & $\begin{array}{l}\text { PET, PAN, PA, PE, PP, } \\
\text { PU, PEI, acrylic, alkyd, } \\
\text { cellulose, rayon }\end{array}$ & $\begin{array}{l}\text { Liu et al. } \\
\text { (2019c) }\end{array}$ \\
\hline France (Paris) & $50-3,250$ & $\begin{array}{l}\text { Range } \\
0.4-59.4 \text { particles } / \mathrm{m}^{3} ; \text { Average } \\
5.4 \text { particles } / \mathrm{m}^{3}\end{array}$ & Fibres & $\mathrm{RY}, \mathrm{PA}, \mathrm{PE}, \mathrm{PP}$ & $\begin{array}{l}\text { Dris et al. } \\
(2016)\end{array}$ \\
\hline
\end{tabular}

polyamide (PA); polyacrylonitrile (PAN); polyethylene (PE); polyethylenimine (PEI); poly (ethylene phthalate) (PEP); polyethylene terephthalate (PET); polyethylene-vinyl-acetate (PEVA); poly (methyl acrylate) (PMA); polypropylene (PP); polystyrene (PS); polyester urethane (PU); poly (vinyl alcohol) (PVA); polyvinyl chloride (PVC); vinyl chloride/vinyl acetate copolymer (PVCA); poly (N-vinyl carbazole) (PVK); styrene butadiene rubber copolymer (SBR); extruded polystyrene (XPS).

that MPLs in mussels were approximately a thousand-fold higher, per unit weight or volume than in the surrounding sediment and water, showing the potential of bioaccumulation of filter-feeding organisms.

As can be seen in Table 1, the prevalent morphotypes were microfibres. Regarding polymers, the most detected were polyethylene (PE), polypropylene (PP), polyethylene terephthalate (PET), and the polyamide group (PA).

On the other hand, despite the number of studies on MPLs in the GIT of fishes (Schirinzi et al., 2020; Abidli et al., 2021; Hadibarata et al., 2021; Ghosh et al., 2021; Li et al., 2021; Zhang et al., 2021), only a reduced number of studies considered the edible parts. Daniel et al. (2020) (Daniel et al., 2020) recently carried out a study in which they compared the MPLs in edible and non-edible parts of pelagic fish for human consumption, showing that MPLs in the GIT of fishes was much higher than in edible parts, such as muscle. In another study, Barbosa et al. (2020) (Barboza et al., 2020) studied the distribution of MPLs in the GIT, gills and dorsal muscle of 3 fish species, Dicentrachus labrax, Trachurus, Scomber colias, and $49 \%$ had MPLs, while $32 \%$ had MPLs in dorsal muscle, with a total mean $( \pm$ SD) of $0.054 \pm 0.099 \mathrm{MPLs}$ items $/ \mathrm{g}$. The results again showed higher results in the GIT and gills than in the edible parts of the 3 studied species. $1.3 \pm 2.5 ; 1.0 \pm 1.9 ; 1.2 \pm 1.6$ MPLs 
TABLE 3 | Selection of toxicological studies using human cell-lines.

\begin{tabular}{|c|c|c|c|c|}
\hline Cells & Cell-tissues & Particle characteristics & Effect evaluated & References \\
\hline $\mathrm{RBL}-2 \mathrm{H} 3$ & Mast & $\begin{array}{l}\text { PS-MNPLs of } 50,500, \text { and } \\
5,000 \mathrm{~nm}\end{array}$ & Internalisation and release & Liu et al. (2021a) \\
\hline Caco-2 & Human colon & $\begin{array}{l}\text { PS-MNPLs of } 100 \text { and } \\
5,000 \mathrm{~nm}\end{array}$ & $\begin{array}{l}\text { Cytotoxicity (cell viability, oxidative stress, and } \\
\text { membrane integrity). }\end{array}$ & Wu et al. (2019) \\
\hline Caco-2 & Human colon & $\begin{array}{l}\text { PS-MNPLs of } 100 \text { and } \\
5,000 \mathrm{~nm}\end{array}$ & Cytotoxicity (cell viability and genomics). & Wu et al. (2020) \\
\hline $\begin{array}{l}\text { Caco-2 } \\
\text { HT29-MTX-E12, human blood } \\
\text { monocyte-derived macrophages and } \\
\text { dendritic cells }\end{array}$ & Human colon & $\begin{array}{l}\text { Different compositions } \\
50 \text { and } 500 \mu \mathrm{m}\end{array}$ & $\begin{array}{l}\text { Cytotoxicity (Inflammatory endpoints, including the } \\
\text { cytokines IL-8, TNF } \alpha \text { and IL-1 } \beta \text {, as well as changes in } \\
\text { the barrier integrity). }\end{array}$ & $\begin{array}{l}\text { Lehner et al. } \\
\text { (2020) }\end{array}$ \\
\hline Caco-2 & Human colon & $\begin{array}{l}\text { PS-MNPLs of } 100 \text { and } \\
5,000 \mathrm{~nm} \\
\text { Pristine and transformed } \\
\text { particles by digestive process }\end{array}$ & $\begin{array}{l}\text { Cytotoxicity comparison between digested and } \\
\text { pristine particles }\end{array}$ & Liu et al. (2020) \\
\hline Caco-2, HepG2 and HepaRG & $\begin{array}{l}\text { Human colon and } \\
\text { liver }\end{array}$ & $\begin{array}{l}\text { PE, PP, PET and PVC } \\
1-4 \mu \mathrm{m}\end{array}$ & Uptake and transport & $\begin{array}{l}\text { Stock et al. } \\
(2021)\end{array}$ \\
\hline A549 & $\begin{array}{l}\text { Human lung } \\
\text { alveolar epithelial } \\
\text { cells }\end{array}$ & $\begin{array}{l}\text { PS-NPLS } \\
25 \text { and } 70 \mathrm{~nm}\end{array}$ & $\begin{array}{l}\text { Internalisation, cell viability, cell cycle, apoptosis, and } \\
\text { associated gene transcription and protein expression }\end{array}$ & Xu et al. (2019) \\
\hline BEAS-2B & $\begin{array}{l}\text { Human lung } \\
\text { normal epithelial } \\
\text { cells }\end{array}$ & $\begin{array}{l}\text { PS-MPLs with an average size } \\
\text { of } 1.72 \pm 0.26 \mu \mathrm{m}\end{array}$ & Cytotoxic and inflammatory effects & $\begin{array}{l}\text { Dong et al. } \\
\text { (2020) }\end{array}$ \\
\hline A549 & $\begin{array}{l}\text { Human lung } \\
\text { alveolar epithelial } \\
\text { cells }\end{array}$ & $\begin{array}{l}\text { PS-MPLs) of } 1 \text { and } 10 \mu \mathrm{m} \\
\text { diameter }\end{array}$ & $\begin{array}{l}\text { Cell proliferation, cytotoxicity } \\
\text { Metabolic activity }\end{array}$ & $\begin{array}{l}\text { Goodman et al. } \\
\text { (2021) }\end{array}$ \\
\hline T98G and HeLa & & PS-MNPLs & Cytotoxicity (cell viability and ROS effect) & $\begin{array}{l}\text { Schirinzi et al. } \\
(2017)\end{array}$ \\
\hline
\end{tabular}

Polystyrene (PS); polypropylene (PP); polyethylene terephthalate (PET); polyvinyl chloride (PVC).

per individual in the GIT, $0.8 \pm 1.4 ; 0.7 \pm 1.4 ; 0.7 \pm 1.0$ MPLs per individual in the gills, and $0.4 \pm 0.7 ; 0.7 \pm 1.3 ; 0.6 \pm 0.8$ MPLs per $\mathrm{g}$, in the dorsal muscle of D. labrax, T. trachurus, and S. colias, respectively. In this regard, it should be pointed out that only the smallest particles can be internalised and translocated, while to date due to technical reasons, most of the studies are not considering the evaluation of NPLs,. Therefore, there is an important gap in the knowledge about NPL contamination in the edible parts of fishes.

Another source of MNPL contamination can be packaging. Nevertheless, there are scant studies that have considered the potential of MNPL transfer from plastic cans (holding drinks or food) and plastic films. Recently, Akhbarizedeh et al. (Akhbarizadeh et al., 2020a) assessed the abundance and composition of MPLs in canned fish. This study showed that $80 \%$ of samples had at least one MPL item, with fibres being the most abundant example. PET was present in $32 \%$ of the samples, which was the most commonly found polymer (Akhbarizadeh et al., 2020a). In another study (Karami et al., 2018), MPL contamination was studied in sardine (Sardina pilchardus) and sprat (Sprattus). In this case, 20 brands of canned sardines and sprats that had been collected in 13 countries were examined. MPLs were confirmed in only four brands, within which, between 1 and
3 MPL particles were found, and polypropylene (PP) and polyethylene terephthalate (PET) were the identified polymers.

In addition to seafood and fish, drinking water is a significant potential source of MNPLs in the human diet. As shown in Table 1, several studies reported the presence of MNPLs in potable tap water. In these studies, both fibres and fragments had been identified. Despite the fact that PVC is one of the most used polymers in pipes was marginally detected in tap water, while polyethylene (PE), Polystyrene (PS), PET and fibres of polyester were those that were more frequently confirmed. In most of the studies, MNPLs in tap water were present in frequencies superior to $90 \%$. However, the concentration of the particles was very variable between the different studies. In this case, the results were highly dependent on the different analytical approaches used, ranging from optical microscopy, scanning electron microscopy (SEM), techniques based on Fourier Transform Infrared (FTIR) spectrometry, and Raman spectrometry, and their capacity to measure the range of the smallest particles. Harmonised methods are urgently needed for drinking water and other food matrices (Oßmann, 2021). Moreover, in the case of drinking water it is particularly relevant to measure the range from NPLs to a few $\mu \mathrm{m}$, as well as the combination with other analytical techniques that are able to provide polymer concentrations per litre of water, such as 
liquid chromatography coupled to high-resolution mass spectrometry (LC-HRMS) (Schirinzi et al., 2019) or gas chromatography pyrolysis mass spectrometry (GC-Pyr-MS) because concentrations in terms of the mass of polymer in water can differ in the counting particles of each polymer, and other techniques are not able to provide an assessment of NPLs. Nevertheless, from the toxicological perspective, especially the smallest MNPLs $(<1.5 \mu \mathrm{m})$ might be toxicologically relevant, in agreement with the European Food Safety Authority (EFSA) (Efsa, 2016).

To carry out the toxicological assessment, often only particle numbers and sizes are used, and only sometimes also concentrations in mass per litre are considered. Recently, the World Health Organization (WHO), in its report on MPs in drinking water (Who, 2019), revisited this issue.

As happens in tap water, high variability was found when comparing different studies on bottled water (Akhbarizadeh et al., 2020b). The most common polymer that was found in bottled water was PET, which is generally used for bottle production and also PP, which is used for the caps. Therefore, these data suggest that the contamination is at least partially coming from the packaging and/or the bottling process itself.

Another studied foodstuff matrix was sea salt, but as happens with water, the comparison of the different studies cannot be made, in particular, because the different studies were carried out using different techniques (optical microscopy, FTIR, GC-PyrMS), and some of these techniques, such as optical microscopy, only provide information on bigger particles.

A minor number of studies considered other food matrices such as soft drinks (Shruti et al., 2020a). Thus, very few studies estimated the intake of MPLs through the diet. Focussing on the diet in the United States, Cox et al. (2019) (Cox et al., 2019) estimated the intake of MPLs. Evaluating approximately $15 \%$ of American's caloric intake, MNPL consumption ranges were from 39,000 to 52,000 particles/person per year depending on age and sex. Additionally, individuals who drink only bottled water may be ingesting an additional 90,000 MNPLs annually, compared to 4,000 MNPLs for those who consume only tap water. Notwithstanding, food preparation and cooking can influence the average MNPL concentrations in meals (Rist et al., 2019). Thus, the comparison between raw foods and final meals is required to assess human exposure to MPLs through the diet.

\section{Inhalation}

MNPL inhalation is considered to be one of the main routes of human exposure. Once inhaled, MNPLs reach the respiratory epithelium and, according to the lessons learned from particulate matter and nanomaterials investigations, it is expected that they may translocate via diffusion, direct cellular penetration, or active cellular uptake through endocytic and phagocytic processes. In the alveoli, phagocytosis is the main pathway for the particles with sizes of between 1 and $3 \mu \mathrm{m}$, while the smallest particles could be passively transported via diffusion across membrane pores (Wright and Kelly, 2017). Nonetheless, the number of studies assessing MNPLs in indoor and outdoor environments continues to be scant (Huang et al., 2020). Most of the studies that have been carried out to date were based on the use of $\mu$-FTIR, which limits the assessment of NPLs. These approaches are, in general, composed of sample collection using passive or active samplers with quartz fibre filters (pore size: $2 \mu \mathrm{m}$, diameter: $46.2 \mathrm{~mm}$ ). In most of the sample pre-treatment procedures, after collecting the total suspended particulate, the samples are digested to remove the organic materials. The most widely used digestion approach is the use of $\mathrm{a}_{2} \mathrm{O}_{2}$ solution of $30 \%(\mathrm{v} / \mathrm{v})$, sometimes with heating to speed up the process. Similar approaches are also well used in the assessment of atmospheric fallout but, in general, they are using passive collectors with different types of filters such as glass fibre filters (Dris et al., 2015), quartz fibre filters (Dris et al., 2016), nitrocellulose filters (Zhou et al., 2017), and PTFE filters (Allen et al., 2019).

As shown in Table 2, fibres are generally the most common MPLs that are identified in outdoor atmospheres. The analytical method that is employed can limit the range of particles that can be assessed. Nowadays, there is a continued existence of a critical gap of knowledge about the minor-sized particle fraction, which can be inhaled. On the other hand, relatively few research articles have considered indoor environments. In order to assess human exposure to indoor airborne MPLs, a breathing thermal manikin was used by Vianello et al. (Vianello et al., 2019) and those authors investigated MPLs down to $11 \mu \mathrm{m}$ particle size. The manikin was used to investigate 3 different habited apartments, and the concentrations were found between 1.7 and 16.2 particles $\mathrm{m}^{-3}$, but only $4 \%$ were MPLs, with polyester being the predominant polymer in $81 \%$, followed by PE in $5 \%$, and $\mathrm{PA}$ in $3 \%$. Another relevant result of this study was that the MPLs were typically of a smaller size than the non-synthetic particles. Zhang et al. (2020a) (Zhang et al., 2020a) studied MPL fallout in different indoor environments, and they established that dormitories were the rooms with a higher abundance of MPLs (average 9,900 MPLs $/ \mathrm{m}^{2} /$ day). In addition, airflow turbulence by the use of an air conditioner increased the resuspension of MPLs. In another study, the presence of MPLs in indoor dust was investigated in the city of Surabaya (Indonesia). The deposition was assessed in an apartment, an office, and a school (Bahrina et al., 2020). The greatest concentration was found in the office with an average of $1,186.36$ particles $/ \mathrm{m}^{2}$, and most of the MPLs were fibres. PET, polyester, and cellophane (CP) were the main polymers detected. Recently, in another study, thirty-two airborne indoor deposited dust samples were studied in homes in Sydney (Australia) (Soltani et al., 2021). MPL fibre deposition rate ranged from 22 to 6,169 fibres $/ \mathrm{m}^{2} /$ day, and most of the deposited dust were fibres (99\%). The majority were natural fibres (42\%), 18\% were transformed natural fibres, and 39\% were MPLs. PE, polyester, PA, and PS were found in higher abundance in homes with carpets. While when the carpet was absent, the polyvinyl fibres were predominant. Mean inhaled MPL weight was estimated to be $0.2 \pm 0.07 \mathrm{mg} / \mathrm{kg}$-body weight (BW)/year and 12,891 $\pm 4,472$ fibres/year. It is noteworthy that the greatest inhalation intake rates were for the age group below 0.5 -years, at $0.31 \mathrm{mg} / \mathrm{kg}-\mathrm{BW} /$ year. As can be seen in these studies, there is a common trend indicating that fibres have predominant shapes. However, the rate of deposition and the rates of inhalation can be extremely 
different according to many factors, such as climate, the use of carpets or an air conditioner, the use of vacuum cleaners, types of textiles, number of habitants in the same place (Pratiwi et al., 2020), among many others, can affect the final rates.

\section{Dermal}

Despite the number of personal care products such as scrubbing powder cleaners, shampoo, facial make-up, and balsams containing MPLs and microbeads in their formulations, and the fact that it has been suggested that there is a potential for NPLs to cross the dermal barrier (Revel et al., 2018), little attention has been paid to assessing dermal exposure. In one of the first studies to assess the potential cytotoxicity of MNPLs, Schirinzi et al. (2017) (Schirinzi et al., 2017) evaluated the effects on human epithelial cells of PE and PS, showing that PS presented Reactive oxygen species (ROS) generation. This is another indication of the importance of assessing the different plastic polymers, rather than considering MNPLs of different materials under the same umbrella. MPLs, and in particular NPLs due to their small size, 3D structure, and apolarity of the majority of polymers, can be internalised by cells (Xu et al., 2019). Moreover, the potential interaction between NPLs and proteins could lead to structural changes of proteins (Hollóczki and Gehrke, 2019) as well as the disruption of the lipid bilayer (Hollóczki and Gehrke, 2020).

\section{PATHWAYS OF MICRO AND NANOPLASTICS IN HUMAN TOXICITY}

MNPLs have a complex nature involving a polymeric matrix with additives such as plasticisers, flame retardants, fillers, UV stabilisers, coating finishers, colourants, metals, among others. Thus, firstly, MNPL toxicity should consider the physical particle damages that can cause inflammatory lesions, originating from the potential of their surface to interact with the tissues. Secondly, MNPL toxicity should also consider the long-term toxicity produced by the plastic additives, which are not covalently bound to the polymer and, once internalised, could be easily released.

Nowadays, most of the information about MNPL toxicity impacting human health is from a limited number of in vitro studies and relevant gaps of information exist. According to the information gathered to date, the Science Advice for Policy by European Academies (SAPEA) project in 2019 considered the lack of evidence on direct adverse effects of MPLs on human health (Sapea, 2019). Furthermore, considering the number of current uncertainties, the European Commission Scientific Advice Mechanism also considered the need to research this field in order to obtain a global perspective compared to other contaminants (not available in Crossref, 2018). As shown in Table 3, some effects cannot be overlooked, and some are dependent on the plastic particle composition, size, and shape. In order to assess the potential toxicity of MNPLs, the capacity of cell internalisation is a central issue. Liu et al. (2021a) (Liu et al., 2021a), using a model cell membrane and rat basophilic leukaemia (RBL-2H3) cells, evaluated the cellular internalisation and release of PS-MNPLs. In that study, both models were exposed to 50,500, and 5,000 nm particles. Those authors showed that 50 and $500 \mathrm{~nm}$ particles were absorbed on the model membrane due to hydrophobic interactions and Van der Waals forces (meaning dispersion forces). This range of particles was also internalised into living cells via both 1) passive membrane penetration because of the partition of PS-MNPLs in the water-phospholipid system and 2) in the case of $50 \mathrm{~nm}$ particles by active endocytosis through the clathrin and caveolin-mediated pathways and mainly by micropinocytosis. As expected endocytosis opens the plasma membrane to $\mathrm{Ca}^{2+}$ influx which could cause the mitochondria dysfunction. In contrast, bigger particles $(5 \mu \mathrm{m}$ cannot be internalised due to their size. The endocytosed 50 and $500 \mathrm{~nm}$ particles mainly accumulate in the lysosomes. In addition to cell internalisation, these particles were also excreted. Finally, it was concluded that masses of the $50 \mathrm{~nm}$ particles that were internalised and excreted were both higher than the masses of $500 \mathrm{~nm}$ (Liu et al., 2021a).

Since ingestion is considered to be the first mode of human exposure, the gastrointestinal tract is one of the first exposure tissues. For this reason, several studies have been carried out to explore the responses in the human colon adenocarcinoma Caco2 cells as a model. Wu et al. have studied whether cytotoxicity of PS particles was size-dependent in exposing Caco-2 cells to PSMNPLs of $5 \mu \mathrm{m}$ and $100 \mathrm{~nm}$ (Wu et al., 2019). In that study, both particle sizes exhibited low toxicity on cell viability, oxidative stress, and membrane integrity. However, the mitochondrial membrane potential was disrupted by both, and on the contrary, as expected, the $5 \mu \mathrm{m}$ particles induced higher effects than those of $100 \mathrm{~nm}$ (Wu et al., 2019). In this case the authors explained that might be due to the different mechanisms of induced mitochondrial depolarization. It was found that $0.1 \mu \mathrm{m}$ PS-MPs accumulated in lysosomes, while $5 \mu \mathrm{m}$ PS-MPs analyses did not reveal accumulation in lysosomes. Large particles at a micrometer scale could escape from the lysosomes after endocytosis and localize in the intracytoplasmic vacuoles or randomly in the cell cytoplasm, which might further damage the lysosomes and induce mitochondrial depolarization and cell apoptosis. Thus, the results from different studies should be compared with caution. In another study by another group, $\mathrm{Wu}$ et al. (2020) investigated the cytotoxicity and the transcriptomic profiles of PS particles in human Caco-2 cells (Wu et al., 2020). That work demonstrated that PS-MPLs reduced cell viability in a dose-dependent manner. The responsible genes were identified by Illumina RNA seq. The dominant pathways related to NF- $\kappa \mathrm{B}, \mathrm{MAPK}$ signalling, cytokine-cytokine receptor interaction, and toll-like receptors, which are involved in modulating cell inflammation and proliferation were strongly influenced. Moreover, the qPCR was applied to investigate the transcriptional level of five proliferation-related genes (Ras, ERK, MER, CDK4, Cyclin D1) and four inflammation-related genes (TRPV1, iNOS, IL-1 $\beta$, IL-8), and the results were consistent with RNA-seq data. Lehner et al. (2020) (Lehner et al., 2020) designed a novel, three-dimensional in vitro intestinal model, consisting of the human intestinal epithelial cell lines Caco-2 and HT29-MTXE12 as well as human blood monocyte-derived macrophages and 
TABLE 4 | Examples toxicological assays of plastic additives using human cell-lines.

\begin{tabular}{|c|c|c|c|c|c|}
\hline $\begin{array}{l}\text { Additives } \\
\text { class }\end{array}$ & Chemical compounds & Test & Effect & Results summary & Ref \\
\hline \multirow[t]{4}{*}{ Plasticisers } & $\begin{array}{l}\text { Adipate: DEHA Phtalates: } \\
\text { DEHP, DBP }\end{array}$ & $\begin{array}{l}\text { Steroid hormone synthesis in } \\
\text { H295 R cells }\end{array}$ & $\begin{array}{l}\text { Endocrine disruption. } \\
\text { Effects on steroid } \\
\text { hormone synthesis }\end{array}$ & $\begin{array}{l}\text { Even at low concentrations of } \\
\text { exposure ( } \leq 1 \mathrm{mg} / \mathrm{L} \text { or } 2.5 \mu \mathrm{M}) \text { these } \\
\text { chemicals and their metabolites can } \\
\text { cause significant endocrine disrupting } \\
\text { effects }\end{array}$ & Duan et al. (2020) \\
\hline & $\begin{array}{l}\text { Bisphenols: BPA, BPF, } \\
\text { BPS, TBBPA }\end{array}$ & $\begin{array}{l}\text { Human embryonic stem cells } \\
\text { H9 using RNA-sequencing } \\
\text { exploring impacts in the } \\
\text { estrogen receptor negative }\end{array}$ & $\begin{array}{l}\text { Effects of BPA and its } \\
\text { analogues in stem cells } \\
\text { to explore potential } \\
\text { developmental impacts }\end{array}$ & $\begin{array}{l}\text { BPA, BPF, and BPS have similar } \\
\text { potencies in inducing transcriptional } \\
\text { changes and perturb many of the } \\
\text { same pathways. TBBPA, the least } \\
\text { structurally similar of the group, } \\
\text { exhibited much lower disrupting } \\
\text { potency }\end{array}$ & $\begin{array}{l}\text { Peshdary et al. } \\
(2021)\end{array}$ \\
\hline & $\begin{array}{l}\text { Bisphenols: BPA, NP, OP } \\
\text { Phthalates: (BBP), (DBP), } \\
\text { (DEHP), (DMP) }\end{array}$ & Human placenta JEG-3 cells & $\begin{array}{l}\text { Cytotoxicity } \\
\text { ROS effect }\end{array}$ & $\begin{array}{l}\text { After } 24 \text { h exposure, OP and NP } \\
\text { showed the highest cytotoxicity }\left(\mathrm{EC}_{50} \text { : }\right. \\
36-40 \mu \mathrm{M}) \text { followed by BPA } \\
(138-219 \mu \mathrm{M}), \text { whereas no significant } \\
\text { toxicity was observed for phthalates. } \\
\text { Notwithstanding, BBP and DBP } \\
\text { significantly decreased P450 } \\
\text { aromatase activity, while NP and OP } \\
\text { increased the activity }\end{array}$ & $\begin{array}{l}\text { Pérez-Albaladejo } \\
\text { et al. (2017) }\end{array}$ \\
\hline & DINCH & $\begin{array}{l}\text { human liver and kidney cell } \\
\text { lines }\end{array}$ & $\begin{array}{l}\text { cytotoxicity and } \\
\text { genotoxicity }\end{array}$ & $\begin{array}{l}\text { DINCH produced oxidative DNA } \\
\text { transient damage in liver cells exposed } \\
\text { for } 3 \mathrm{~h} \text {. DINCH may be hazardous to } \\
\text { humans and further investigation is } \\
\text { necessary to warrant its safety }\end{array}$ & $\begin{array}{l}\text { Vasconcelos et al. } \\
\text { (2019) }\end{array}$ \\
\hline
\end{tabular}

\begin{tabular}{lll}
\hline Phtalates: DEHP & Human embryonic stem cells & Endocrine disruption \\
& H9-hESC & and embriotoxicity
\end{tabular}

Inhibition of cell proliferation,

Fang et al. (2019a) promotion of cell cycle arrest, and induced apoptosis through the PPAR $\gamma /$ PTEN/AKT signalling pathway. Suggesting potential reproductive or developmental toxicity

\begin{tabular}{|c|c|c|c|c|}
\hline $\begin{array}{l}\text { Phtalates: DEHT and their } \\
\text { human metabolites } 5-\mathrm{OH}- \\
\text { MEHP and MEHT }\end{array}$ & Thyroid/hormone receptors & Endocrine disruption & $\begin{array}{l}\text { lack of interactions between oxidised } \\
\text { metabolites and thyroid hormone } \\
\text { receptors, confirming the interest in } \\
\text { DEHT as substitute of DEHP }\end{array}$ & $\begin{array}{l}\text { Kambia et al. } \\
\text { (2021) }\end{array}$ \\
\hline $\begin{array}{l}\text { Phthalates and PE-NPLs: } \\
\text { BBP, DBP, DEHP }\end{array}$ & $\begin{array}{l}\text { Human lung epithelial A549 } \\
\text { cells }\end{array}$ & $\begin{array}{l}\text { Cytotoxicity (oxidative } \\
\text { stress and inflammation) }\end{array}$ & $\begin{array}{l}\text { Oxidative stress and inflammatory } \\
\text { reactions were mechanisms for } \\
\text { combined cytotoxicity }\end{array}$ & Shi et al. (2021) \\
\hline $\begin{array}{l}\text { Phthalates: BBP, DBP, } \\
\text { DEHP } \\
\text { Phtalate substitutes: } \\
\text { ATBC, ATEC, ATHC }\end{array}$ & $\begin{array}{l}\text { Human keratinocyte cell line } \\
\text { HaCaT }\end{array}$ & Cytotoxicity & $\begin{array}{l}\text { ATEC showed similar levels of } \\
\text { cytotoxicity with the phthalates, } \\
\text { whereas ATBC and ATHC did not } \\
\text { show significant cytotoxicity. even in } \\
\text { high doses }(5 \mathrm{mg} / \mathrm{ml})\end{array}$ & Kim et al. (2019) \\
\hline $\begin{array}{l}\text { Phthalates: DBP, BBP, } \\
\text { and their metabolites: } \\
\text { MBP and MBzP }\end{array}$ & $\begin{array}{l}\text { Human erythrocytes } \\
\text { cytotoxicity }\end{array}$ & $\begin{array}{l}\text { Cytotoxicity (haemolysis } \\
\text { and erytopsis) }\end{array}$ & $\begin{array}{l}\text { DBP and BBP possess higher } \\
\text { haemolytic properties compared to } \\
\text { their metabolites } \\
\mathrm{LC}_{50} \text { was } 126.37 \pm 5.94 \mu \mathrm{g} / \mathrm{ml} \text { for } \\
\mathrm{DBP} \text {, and } 103.65 \pm 4.03 \mu \mathrm{g} / \mathrm{ml} \text { for } \\
\mathrm{BBP} \text {, and for metabolites this value } \\
\text { was over } 500 \mu \mathrm{g} / \mathrm{ml}\end{array}$ & Sicińska, (2018) \\
\hline $\begin{array}{l}\text { Phthalates: DEHP and } \\
\text { MEHP }\end{array}$ & Alveolar epithelial A549 cells & $\begin{array}{l}\text { Evaluation of the cell } \\
\text { progression, epithelial } \\
\text { and mesenchymal } \\
\text { markers }\end{array}$ & $\begin{array}{l}\text { DEHP and MEHP altered the structure } \\
\text { and migration of A549 cells and } \\
\text { promoted the loss of the epithelial } \\
\text { phenotype }\end{array}$ & $\begin{array}{l}\text { Rafael-Vázquez } \\
\text { et al. (2018) }\end{array}$ \\
\hline
\end{tabular}


TABLE 4 | (Continued) Examples toxicological assays of plastic additives using human cell-lines.

$\begin{array}{lll}\text { Flame retardants } & \text { Organophosphate } & \text { Human liver hepatocellular } \\ \text { TBOEP } & \text { carcinoma cell line, HepG2 } & \text { changes in gene } \\ & \text { transcription }\end{array}$

TBOEP treatments resulted in increases in cell metabolism could explain the increase in mitochondrial activity at lower TBOEP concentrations. In addition, showed effects on steroid hormone biosynthesis and regulation, and potentiation of immune responses

\begin{tabular}{ll}
\hline Organophosphate & Human liver hepatocellular \\
TCP & carcinoma cell line, HepG2
\end{tabular}

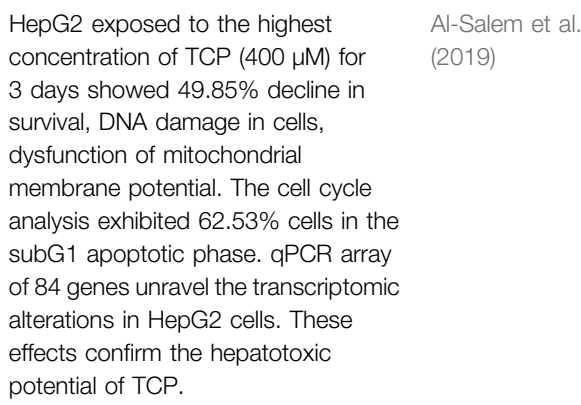

Al-Salem et al (2019)

\begin{tabular}{|c|c|c|c|c|}
\hline $\begin{array}{l}\text { Organophosphate: } \\
\text { EHDPP, TPCP, TOCP, } \\
\text { TPHP, TCP and CDP }\end{array}$ & $\begin{array}{l}\text { Human normal liver } \\
\text { hepatocytes (LO2) }\end{array}$ & Hepatotoxicity & $\begin{array}{l}10 \mathrm{mg} / \mathrm{L} \text { of EHDPP significantly } \\
\text { affected energy homeo-stasis, } \\
\text { endoplasmic reticulum (ER) stress, } \\
\text { apoptosis, cell cycle, and inflammation } \\
\text { response in cells }\end{array}$ & Zhu et al. (2021) \\
\hline $\begin{array}{l}\text { PBDEs: quinone-type } \\
\text { metabolite of PBDEs } \\
\text { (PBDEQ) }\end{array}$ & $\begin{array}{l}\text { Human normal liver } \\
\text { hepatocytes (LO2) }\end{array}$ & Hepatotoxicity & $\begin{array}{l}\text { PBDEQ-induced protein oxidative } \\
\text { damage in LO2 cells }\end{array}$ & Wang et al. (2021b) \\
\hline
\end{tabular}

Krivoshiev et al. (2018) 
The GIT uptake and effects of different MPLs of most common polymers (PE, PP, PET and PVC) were investigated by Stock et al. (Stock et al., 2021) using the Caco-2 cell line as the in vitro cell-line model and using the cytotoxicity of the human cell lines Caco-2, HepG2 and HepaRG in order to detect a possible impact on the organs which are first to come into contact with ingested particles: the intestine and the liver. The results of the study demonstrate that especially 1-4 $\mu \mathrm{m}$ PE-MPLs were transported through the intestinal epithelium and that intestinal exposure to MPLs is material- and size-dependent. However, it should be highlighted that only a high concentration far beyond realistic dietary exposure of consumers induced cytotoxic effects.

Although much less investigation has been undertaken in exploring the potential cytotoxicity of MNPLs in other tissues, several studies were carried out during recent years. Xu et al. (2019) (Xu et al., 2019) carried out a preliminary evaluation of the effects of PS-NPLs on human lung epithelial cells. The internalisation, cell viability, cell cycle, apoptosis, and associated gene transcription and protein expression were assessed on the human alveolar epithelial A549 cell line exposed to 25 and $70 \mathrm{~nm}$ PS-NPLs. Results showed that smaller particles were internalised more rapidly and efficiently into the cytoplasm of A549. PS-NPLs significantly affected the cell viability, induced significant upregulation of pro-inflammatory cytokines such as IL-8, NF- $\mathrm{B}$, TNF- $\alpha$, and pro-apoptotic proteins such as DR5, caspase-3, caspase- 8 , caspase- 9 , and cytochrome $c$, which revealed that it triggered a TNF- $a$-associated apoptosis pathway. That study suggests that exposure duration, diameter, and concentration are the key factors in the toxicological effects of PS-NPLs on alveolar epithelial cells. In another study by Dong et al. (2020) (Dong et al., 2020), the potential of in vitro pulmonary toxicity of PS-MPLs was assessed using normal human lung epithelial
BEAS-2B cells. PS-MPLs with an average size of $1.72 \pm 0.26 \mu \mathrm{m}$ were used. Results revealed that PS-MPLs could cause cytotoxic and inflammatory effects in BEAS-2B cells by inducing reactive oxygen species (ROS) formation. PS-MPLs can decrease transepithelial electrical resistance by depleting zonula occludens (ZO) proteins. According to the authors, high concentrations of PS-MPLs produce the decreased a1-antitrypsin levels, increasing the risk of chronic obstructive pulmonary disease. Furthermore, low levels of PS-MPLs can disrupt the protective pulmonary barrier, and they may also increase the risk of lung disease. These findings indicate that PS-MPL inhalation may negatively influence human respiratory health. The potential toxicological damages of PS-MPLs in lung cell were also proposed by Goodman et al. (2021) (Goodman et al., 2021). In that study, human alveolar A549 cells were exposed to polystyrene microplastics (PS-MPLs) of 1 and $10 \mu \mathrm{m}$ diameter. Both sizes caused a significant reduction in cell proliferation but exhibited little cytotoxicity. Despite these results, further assays revealed the metabolic activity decrease and a dramatic decrease in the proliferation rate of exposed cells. Phase-contrast imaging of live cells revealed at $72 \mathrm{~h}$ major changes in exposed cells morphology, as well as the uptake of $1 \mu \mathrm{m}$ particles into the cells. Confocal fluorescent microscopy at $24 \mathrm{~h}$ of exposure confirmed the incorporation of $1 \mu \mathrm{m}$ PS-MPLs.

Other studies have focussed on the potential genotoxic effects of PE on peripheral blood lymphocytes (Çobanoğlu et al., 2021) and the ROS effect on T98G and HeLa, cerebral and epithelial human cells, respectively (Schirinzi et al., 2017). In conclusion, the main toxicological effects that can be attributed to MNPLs particles are oxidative stress, cytotoxicity, and metabolic changes. However, the composition of the particles and the dose drive the toxicological properties, size, shape, surface functionalisation, or surface properties.

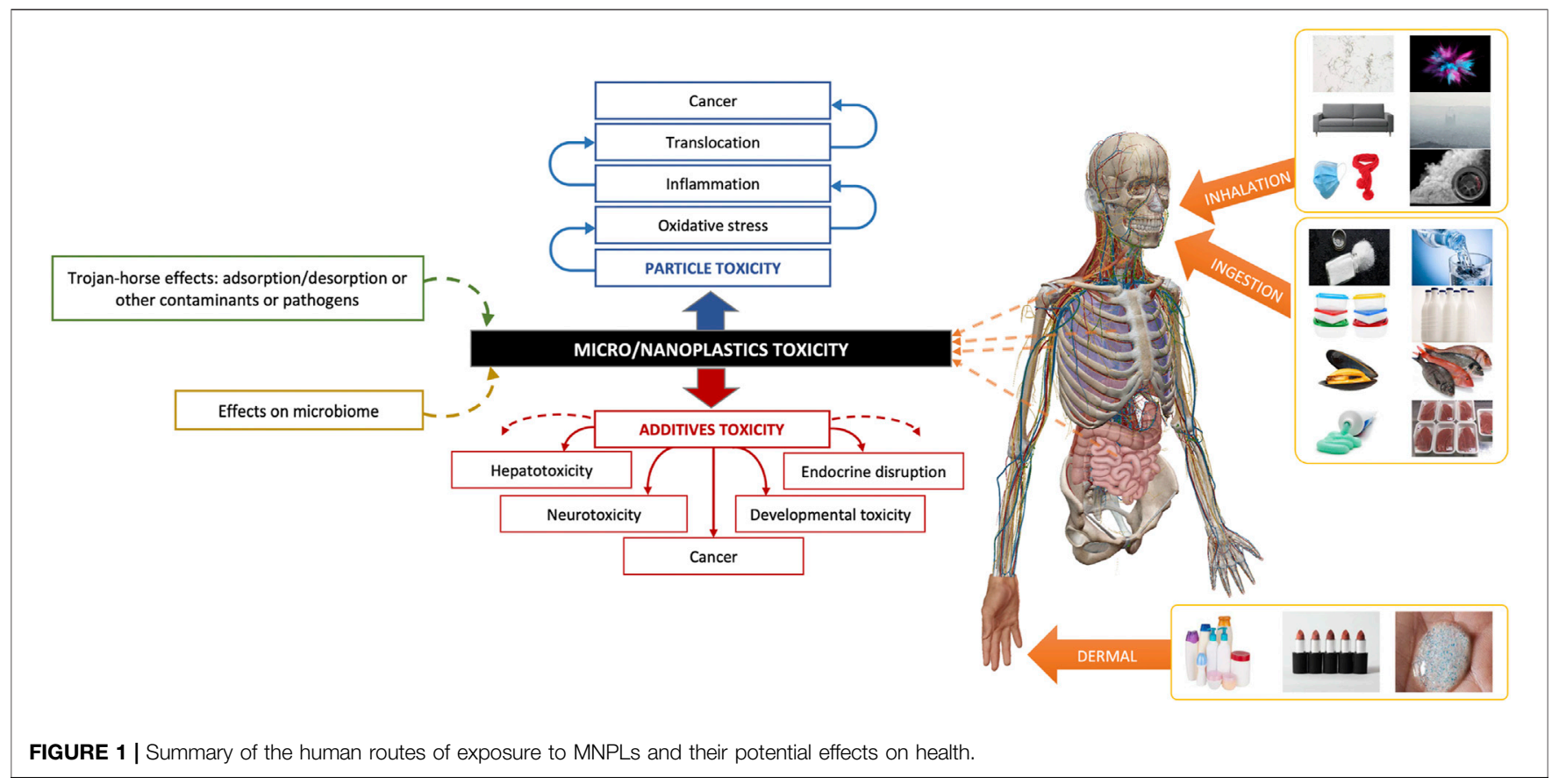




\section{PATHWAYS OF PLASTIC ADDITIVE TOXICITY}

Plastic formulations are composed of polymer or polymer mixtures and plastic additives, including functionalising agents (plasticisers, impact modifiers, and flame retardants), stabilisers (antioxidants, UV-filters, thermal stabilisers), lubricants, fillers, and colourants. The additives are incorporated into the polymers during manufacture, but they are not chemically bound to them, as aforementioned. Due to this reason and their low molecular weight, plastic additives can leach the external medium along a concentration gradient (Tickner et al., 2001).

As mentioned before, when particle size decreases, the surfaceactive area in contact with the external medium will increase, facilitating the leach. If MNPLs accumulate in living organisms, they present a source of chemical plastic additives and polymer monomers to tissues and fluids.

Indeed, the impacts on human health of some selected groups of plastic additives such as polybrominated diphenyl ethers (PBDEs) (Maddela et al., 2020), bisphenol A (Kahn et al., 2020; Meli et al., 2020; Mustieles and Fernández, 2020a), and some phthalates (Sedha et al., 2021) have been extensively studied in the last 10 years, and relevant hazard and epidemiological information (Husøy et al., 2019) have been collected. These chemicals have been related to carcinogenicity, neurotoxicity (Mustieles and Fernández, 2020b; Li et al., 2020), obesity (Andújar et al., 2019), and endocrine disruption (Ma et al., 2019). Human studies showed that the concentrations of these additives in young children, a susceptible segment (Ma et al., 2019; Ouyang et al., 2020), are typically higher, indicating the need to decrease exposure to these compounds. Thus, a wide variety of substitution compounds have arisen in new plastic formulations, including emerging plasticisers, brominated flame retardants (BFR) and organophosphate esters (OPEs) in substituting PBDE legacies, or those used in new plastic materials such as bioplastics. Bioplastics derived from renewable biomass sources such as polylactic acid (PLA), polyhydroxyalkanoates (PHA), bio-derived polyethylene (Bio$\mathrm{PE})$, among many others, offer a greener solution for plastic production. However, very little information is currently available on their impact on living organisms, including humans. In this sense, Zimmermann et al. (2019) (Zimmermann et al., 2019) demonstrated that consumer products made of PLA induced strong baseline toxicity similar to PVC items. This demonstrates that this bio-based and biodegradable material, despite being marketed as better alternative, is not necessarily safer than conventional plastics. Despite the amount of research that has been devoted to assessing the potential impact of certain groups of plastic additives, such as some plasticisers and flame retardants, the information about the other groups continues to be scant. As can be seen in Table 4, this tendency has continued in recent years and most of the investigations have been focussed on plasticisers of the group of phthalates and bisphenols, and the new organ phosphate flame retardants. In addition to many toxicological studies showing the negative effects of certain phthalate congeners on human health, such as asthma, breast cancer, obesity, type II diabetes, and male infertility, the potential health damages by new substitution compounds, the phthalate transformation products, or even human metabolites of primary phthalates are open questions. In this regard, Sicińska (Sicińska, 2018), undertook an in vitro study of the induction of haemolysis and eryptosis in human erythrocytes caused by di-n-butyl phthalate (DBP), butyl benzyl phthalate (BBP), and their metabolites: mono-n-butyl phthalate (MBP) and mono-benzyl phthalate (MBzP). The main results of this study demonstrated that DBP and BBP possess higher haemolytic properties compared to their metabolites, but all compounds induced eryptosis.

One of the most commonly used plasticisers is di (2-ethyl hexyl) phthalate (DEHP), which is metabolised to mono (2ethylhexyl) phthalate (MEHP), and inhalation is an important exposure route for both. Their effects on the lungs include inflammation and alteration of postnatal maturation (alveolarisation). Recently, the cell progression, epithelial and mesenchymal markers were studied in alveolar epithelial cells A549, exposed to DEHP (1-100 $\mu \mathrm{M})$ or MEHP $(1-50 \mu \mathrm{M})$ for 24-72 h (Sedha et al., 2021). That experimental work showed that DEHP and MEHP altered the structure and migration of A549 cells and promoted the loss of the epithelial phenotype (RafaelVázquez et al., 2018). DEHP has been classified as an endocrine disruptor. Fang et al. (Fang et al., 2019a) investigated the mechanism of the embryotoxicity induced by DEHP in differentiated human embryonic stem cells (hESCs). It was demonstrated that DEHP exposure inhibited cell proliferation, promoted cell cycle arrest, and induced apoptosis through the PPAR $\gamma /$ PTEN/AKT signalling pathway, suggesting that DEHP exposure could cause reproductive or developmental toxicity in humans (Fang et al., 2019a).

Due to the endocrine disruption effects of different phthalates, currently, a series of substitutes have been proposed, such as tributyl o-acetylcitrate (ATBC), triethyl 2-acetylcitrate (ATEC), and trihexyl o-acetylcitrate (ATHC). To assess the safety of these new substitutes, the potential cytotoxicity of these compounds was screened in a human keratinocyte cell line $\mathrm{HaCaT}$. The results demonstrated that ATEC showed similar levels of cytotoxicity as common phthalates, whereas ATBC and ATHC did not show significant cytotoxicity, even at very high doses $(5 \mathrm{mg} / \mathrm{ml})$ (Kim et al., 2019).

Another plasticiser with high usage in the past in polycarbonate plastic production is bisphenol-A (BPA). However, BPA exhibits toxicity, endocrine disruption, mutagenicity and carcinogenic effects in living organisms (Maffini et al., 2006; Rochester, 2013). For these reasons, in 2011, the plasticiser use was banned in baby bottles, cups, and other containers that are designed for use by children of 3 years old and younger, and in 2012 their use was also banned in water bottles. Currently, the toxicity of other alternative compounds of this group, such as bisphenol-F (BPF) and bisphenol-S (BPS), and $3,3^{\prime}, 5,5^{\prime}$-tetrabromobisphenol-A (TBBPA) that are also used as a flame retardant, are being investigated. Further, several studies have revealed that these compounds also presented toxicity in specific BPF and BPS (Fouyet et al., 2021).

Another group of plasticisers with increasing use are the adipates, this class of plasticisers has been much less studied 
but recent findings showed that bis (2-ethylhexyl) adipate (DEHA) and their metabolites can cause, even at low concentrations, endocrine-disrupting effects on the steroid hormone synthesis in H295R cell (Duan et al., 2020).

As aforementioned, flame retardants are another group of plastic additives that has been related to different toxicological effects in human health. In particular, some PBDEs are currently listed in Annex A of the Stockholm Convention on Persistent Organic Pollutants with specific exemptions for use regarding the recycling of articles that contain or may contain these chemicals. Thus, these compounds have been replaced by other groups, among them organophosphateflame retardants. Currently, there are some gaps of information about their fate, behaviour and toxicity, but some compounds have been related to human accumulation (Chupeau et al., 2020) and health impairments (Wang et al., 2020a; Chupeau et al., 2020). Among them, there are five main toxicological effects described as reproductive and developmental toxicity (Liu et al., 2021b), neurotoxicity (Yan et al., 2021), hepatotoxicity (Zhu et al., 2021), cardiotoxicity (Reddam et al., 2019; Xiong et al., 2021) and endocrine disruption (Liu et al., 2019a). However, most of these studies were in vivo assays with animals, and some information of toxicity mechanisms from in vitro tests using human cell is still required.

Other chemicals that could leach from the plastic polymer matrix include antioxidants, UV stabilisers such as the group of benzophenones and plastic coating finishing compound such as perfluoroalkyl substances (PFASs) (Pelch et al., 2019), but with the exception of the PFASs group, the potential for adverse effects on human health of other plastic additives has been much less studied.

It is noteworthy that, currently, more than 5,300 plastic formulations are commercially available. More than 4,000 known chemicals are associated with plastic packaging alone, and to date most of these chemicals have not been appropriately studied.

Moreover, in general, the potential migration of additives from the plastics in use is the considered factor for the evaluation of their potential impact. In the case of MNPL contamination from different sources, the potential migration from MNPLs particles during long-term exposure should be assessed. Lixiviation should be evaluated from particles of the smallest range of sizes, with modified surface properties, considering the potential accumulation in tissues, and sometimes coming from plastic formulations that are no longer in use, with residues that are still in the environment.

\section{TROJAN-HORSE EFFECTS AND MICROBIOME EFFECTS}

The increased surface area of MNPLs and their surface properties, such as hydrophobicity and adsorption, favour the accumulation onto their surfaces of other contaminants from surrounding environments, facilitating their potential transfer to living organisms, including humans. Llorca et al. (2018) (Llorca et al., 2018) assessed the adsorption and desorption behaviour of 18 perfluoroalkyl substances (PFASs) from the surrounding waters (freshwater and seawater) of Spain onto MNPLs surfaces of different polymers, including PE, PS, and polystyrene carboxylate (PS-COOH)). Then, the same group investigated the capacity for the transfer of polychlorinated biphenyls (PCBs), a group of persistent organic pollutants (POPs) to PE, PS, and PET MPL surfaces in water/sediment systems (Llorca et al., 2020b). In both studies, the adsorption/desorption of other contaminants onto MNPL surfaces was confirmed, mainly following the Freundlich isotherms. Medium polar compounds showed that the adsorption and posterior desorption increased. While highly non-polar compounds were sequestered onto the MNPL surfaces. Therefore, it should be considered how the interaction of contaminant/MPLs can affect the absolute bioavailability of these contaminants that are transferred to biota. Indeed, several works informed about the potential for the accumulation of environmental pollutants onto MPL surfaces (Lang et al., 2020; Atugoda et al., 2021; Fan et al., 2021; Puckowski et al., 2021; Torres et al., 2021). However, less research has been paid to assessing of whether certain tissue temperatures and physiological conditions can increase the potential transfer of other contaminants to humans. In this regard, the potential for POPs (DDT, PFOA, and DEHP) to desorb from MPLs of PVC and $\mathrm{PE}$ under simulated physiological conditions has been studied (Bakir et al., 2014). Desorption rates were enhanced up to 30 times compared to seawater at lower $\mathrm{pH}$ and higher temperatures, in conditions simulating the physiological conditions of warm organisms, $38^{\circ} \mathrm{C}, \mathrm{pH}$ 4. Therefore, this pathway of human exposure needs to be addressed. In general, the toxicological interaction between MNPLs and other contaminants has been assessed using in vivo studies, the majority of which were focused on the effect on model organisms exposed to a mixture of chemicals or an individual chemical but in both cases at a single concentration. Therefore, dose-response curves were not provided, and a complete description of these interactions was not assessed.

Several factors rule the modulation of the toxicity of MNPLs and other contaminant toxicity such as physicochemical properties of MNPLs and contaminant mixtures, and therefore, their adsorption/desorption behaviour, and that of the selected model organisms. Other essential factors are the size and shape of MNPLs, and even with respect to the colour for some test organisms (Bhagat et al., 2021).

On the other hand, MNPL surfaces are colonised by microbes. In the natural environment, for example, biofilms can be established on plastic particle surfaces within a period of 7 days. Thus, the potential transfer of pathogens via microplastics that are inhaled or ingested should also be investigated.

Finally, another potential effect that should be closely studied is the MNPLs potential to disrupt the human microbiome. The chronic ingestion of MNPLs could impact on the natural community and abundance pattern of the gut microbiota. This so-called dysbiosis could be associated to mechanical disruption within the GIT, the ingestion of foreign and potentially pathogenic bacteria, as well as chemicals, which make-up or 
adhere to MNPLs. The impact on the microbiome can result in the immune system response and trigger chronic diseases, promote infections, and alter the gut microbiota. For example, lipopolysaccharides (LPS) are able to adjust the hydrophobicity in their cell walls by changing their composition in the outer membrane, to better interact with other hydrophobic substances (Krasowska and Sigler, 2014; Rogers et al., 2020). LPS also can effect gut microbiota so changes on LPS will direct affect microbiota (Di Lorenzo et al., 2019). In this regard, Fackelmann and Sommer (Fackelmann and Sommer, 2019) have summarised microplastics-induced gut dysbiosis effects on host health, and some few pioneering studies have been carried out during the last years, studying responses on mice (Lu et al., 2018) and aquatic organisms (Evariste et al., 2019), but this is another human open question for human health implications.

\section{CURRENT NEEDS AND FUTURE RESEARCH TRENDS}

The study of the potential impacts of MNPLs in human health is in an early stage of development. Firstly, the analytical approaches to assess them are limited by the size of the particles, and there are only a few approaches able to assess the particles at the nano-range. Thus, human exposure assessment continues to be a challenge. Moreover, it is expected that small-sized particles are those with a superior rate of up-take and translocation through tissues, but this concordance is not always observed, and it should be better studied. On the other hand, the interaction of MNPLs to lipopolysaccharides needs to be further investigated since the effects of LPS on the gut plays an important role and their release into the blood will damage the endothelium. This needs to be examined because the effects of LPS on the gut is important and the release of LPS into the blood will damage the endothelium.

Particle weathering is also a parameter that should be considered when assessing toxicity of MNPLs- Physical damages caused by particles include the disruption of the immune system, the increase of barriers permeability, leading to oxidative stress and inflammation, favouring the uptake of smallest particles and translocation through tissues. In addition, their higher surface area favours the long-term leach of plastic additives or the transfer to the biota of other contaminants and maybe pathogens. Besides, the potential disturbance of the

\section{REFERENCES}

\section{8.}

Abbasi, S., Keshavarzi, B., Moore, F., Turner, A., Kelly, F. J., Dominguez, A. O., et al. (2019). Distribution and Potential Health Impacts of Microplastics and Microrubbers in Air and Street Dusts from Asaluyeh County, Iran. Environ. Pollut. 244, 153-164. doi:10.1016/j.envpol.2018.10.039

Abidli, S., Akkari, N., Lahbib, Y., Trigui, N., and Menif, E. (2021). First Evaluation of Microplastics in Two Commercial Fish Species from the Lagoons of Bizerte and Ghar El Melh (Northern Tunisia). Reg. Stud. Mar. Sci. 41, 101581. doi:10.1016/j.rsma.2020.101581 human microbiome can be another cause of human health damage almost not studied until now.

The main routes of human exposure have already been established, with ingestion and inhalation being the main routes. Nevertheless, the occurrence of MNPLs in complete diets has not been established to date. Therefore, the total contribution of MNPLs to human exposure of exogenous particles through ingestion is still unknown. Moreover, incidental sources of exposure (MNPLs from food packaging, ingestion from PPCs, among others, have not been well determined). Inhalation is another relevant source of MNPL exposure, but relatively few studies have considered indoor exposure.

There is a need for more comprehensive toxicological studies, including particulate physical damages and the toxicity of additives. In this regard, the information about plastic additive toxicity continues being limited to targeted groups of compounds such as phthalates. In addition, the toxicity of MNPLs is also modulated by their size, shape, and studies comparing these variables are necessary.

Finally, to assess the impacts of MNPLs contamination and their potential damages to human health, cohort studies focussed on this emerging type of contamination are required.

\section{DATA AVAILABILITY STATEMENT}

The original contributions presented in the study are included in the article/Supplementary Material, further inquiries can be directed to the corresponding authors.

\section{AUTHOR CONTRIBUTIONS}

ML has contributed to the design and writing of diffeerent sections of the document. MF concieled the idea of the manuscript, designed it and wrote different sections.

\section{FUNDING}

This work was supported by PLAS-MED and DEGBIOPLAST projects (CTM 2017--89701-C3-1-R and RTI 2018-097860-JI00) from the Spanish Ministry of Science and Innovation.

Akhbarizadeh, R., Dobaradaran, S., Nabipour, I., Tajbakhsh, S., Darabi, A. H., and Spitz, J. (2020). Abundance, Composition, and Potential Intake of Microplastics in Canned Fish. Mar. Pollut. Bull. 160, 111633. doi:10.1016/ j.marpolbul.2020.111633

Akhbarizadeh, R., Dobaradaran, S., Schmidt, T. C., Nabipour, I., and Spitz, J. (2020). Worldwide Bottled Water Occurrence of Emerging Contaminants: A Review of the Recent Scientific Literature. J. Hazard. Mater. 392, 122271. doi:10.1016/j.jhazmat.2020.122271

Akhbarizadeh, R., Moore, F., and Keshavarzi, B. (2019). Investigating Microplastics Bioaccumulation and Biomagnification in Seafood from the Persian Gulf: a Threat to Human Health. Food Additives \& Contaminants: A 36 (11), 1696-1708. doi:10.1080/19440049.2019.1649473 
Al-Salem, A. M., Saquib, Q., Siddiqui, M. A., Ahmad, J., Wahab, R., and AlKhedhairy, A. A. (2019). Organophosphorus Flame Retardant (Tricresyl Phosphate) Trigger Apoptosis in HepG2 Cells: Transcriptomic Evidence on Activation of Human Cancer Pathways. Chemosphere 237, 124519. doi:10.1016/ j.chemosphere.2019.124519

Allen, S., Allen, D., Phoenix, V. R., Le Roux, G., Durántez Jiménez, P., Simonneau, A., et al. (2019). Atmospheric Transport and Deposition of Microplastics in a Remote Mountain Catchment. Nat. Geosci. 12 (5), 339-344. doi:10.1038/ s41561-019-0335-5

Andrady, A. L. (2011). Microplastics in the marine Environment. Mar. Pollut. Bull. 62 (8), 1596-1605. doi:10.1016/j.marpolbul.2011.05.030

Andrady, A. L., and Neal, M. A. (2009). Applications and Societal Benefits of Plastics. Phil. Trans. R. Soc. B. 364 (1526), 1977-1984. doi:10.1098/ rstb.2008.0304

Andújar, N., Gálvez-Ontiveros, Y., Zafra-Gómez, A., Rodrigo, L., Álvarez-Cubero, M. J., Aguilera, M., et al. (2019). Bisphenol A Analogues in Food and Their Hormonal and Obesogenic Effects: A Review. Nutrients 11 (9). doi:10.3390/ nu11092136

Atugoda, T., Vithanage, M., Wijesekara, H., Bolan, N., Sarmah, A. K., Bank, M. S., et al. (2021), Interactions between Microplastics, Pharmaceuticals and Personal Care Products: Implications for Vector Transport. Environ. Int. 149. 106367. doi:10.1016/j.envint.2020.106367

Baechler, B. R., . Granek, E. F., Mazzone, S. J., Nielsen-Pincus, M., and Brander, S. M. (2020). Microplastic Exposure by Razor Clam Recreational HarvesterConsumers along a Sparsely Populated Coastline. Front. Mar. Sci. 7. doi:10.3389/fmars.2020.588481

Bahrina, I., Syafei, A., Satoto, R., Jiang, J.-J., Nurasrin, N., Assomadi, A., et al. (2020). An Occupant-Based Overview of Microplastics in Indoor Environments in the City of Surabaya, Indonesia. J. Ecol. Eng. 21 (8), 236-242. doi:10.12911/ 22998993/126876

Bakir, A., Rowland, S. J., and Thompson, R. C. (2014). Enhanced Desorption of Persistent Organic Pollutants from Microplastics under Simulated Physiological Conditions. Environ. Pollut. 185, 16-23. doi:10.1016/ j.envpol.2013.10.007

Barboza, L. G. A., Lopes, C., Oliveira, P., Bessa, F., Otero, V., Henriques, B., et al. (2020). Microplastics in Wild Fish from North East Atlantic Ocean and its Potential for Causing Neurotoxic Effects, Lipid Oxidative Damage, and Human Health Risks Associated with Ingestion Exposure. Sci. Total Environ. 717, 134625. doi:10.1016/j.scitotenv.2019.134625

Besseling, E., Wegner, A., Foekema, E. M., van den Heuvel-Greve, M. J., and Koelmans, A. A. (2013). Effects of Microplastic on Fitness and PCB Bioaccumulation by the Lugworm Arenicola marina (L.). Environ. Sci. Technol. 47 (1), 593-600. doi:10.1021/es302763x

Bhagat, J., Nishimura, N., and Shimada, Y. (2021). Toxicological Interactions of Microplastics/nanoplastics and Environmental Contaminants: Current Knowledge and Future Perspectives. J. Hazard. Mater. 405, 123913. doi:10.1016/j.jhazmat.2020.123913

Bonello, G., Varrella, P., and Pane, L. (2018). First Evaluation of Microplastic Content in Benthic Filter-Feeders of the Gulf of La Spezia (Ligurian Sea). J. Aquat. Food Product. Tech. 27 (3), 284-291. doi:10.1080/ 10498850.2018.1427820

Bouwmeester, H., Hollman, P. C. H., and Peters, R. J. B. (2015). Potential Health Impact of Environmentally Released Micro- and Nanoplastics in the Human Food Production Chain: Experiences from Nanotoxicology. Environ. Sci. Technol. 49 (15), 8932-8947. doi:10.1021/acs.est.5b01090

Campanale, C., Massarelli, fnm., Savino, fnm., Locaputo, fnm., and Uricchio, fnm. (2020). A Detailed Review Study on Potential Effects of Microplastics and Additives of Concern on Human Health. Ijerph 17 (4), 1212. doi:10.3390/ijerph17041212

Catarino, A. I., Macchia, V., Sanderson, W. G., Thompson, R. C., and Henry, T. B. (2018). Low Levels of Microplastics (MP) in Wild Mussels Indicate that MP Ingestion by Humans Is Minimal Compared to Exposure via Household Fibres Fallout during a Meal. Environ. Pollut. 237, 675-684. doi:10.1016/ j.envpol.2018.02.069

Cho, S. A., Cho, W. B., Kim, S. B., Chung, J. H., Kim, H. J., et al. (2019). Identification of Microplastics in Sea Salts by Raman Microscopy and FT-IR Microscopy. Anal. Sci. Tech. 32 (6), 243-251.

Chupeau, Z., Bonvallot, N., Mercier, F., Le Bot, B., Chevrier, C., and Glorennec, P. (2020). Organophosphorus Flame Retardants: A Global Review of Indoor
Contamination and Human Exposure in Europe and Epidemiological Evidence. Int. J. Environ. Res. Public Health 17 (18), 1-24. doi:10.3390/ ijerph17186713

Çobanoğlu, H., Belivermiş, M., Sıkdokur, E., Kılıç, Ö., and Çayır, A. (2021). Genotoxic and Cytotoxic Effects of Polyethylene Microplastics on Human Peripheral Blood Lymphocytes. Chemosphere 272, 129805. doi:10.1016/ j.chemosphere.2021.129805

Cole, M., Lindeque, P., Halsband, C., and Galloway, T. S. (2011). Microplastics as Contaminants in the marine Environment: A Review. Mar. Pollut. Bull. 62 (12), 2588-2597. doi:10.1016/j.marpolbul.2011.09.025

Coppola, F., Bessa, A., Henriques, B., Russo, T., Soares, A. M. V. M., Figueira, E., et al. (2020). Oxidative Stress, Metabolic and Histopathological Alterations in Mussels Exposed to Remediated Seawater by GO-PEI after Contamination with Mercury. Comp. Biochem. Physiol. A. Mol. Integr. Physiol. 243, 110674. doi:10.1016/j.cbpa.2020.110674

Cox, K. D., Covernton, G. A., Davies, H. L., Dower, J. F., Juanes, F., and Dudas, S. E. (2019). Human Consumption of Microplastics. Environ. Sci. Technol. 53 (12), 7068-7074. doi:10.1021/acs.est.9b01517

Daniel, D. B., Ashraf, P. M., and Thomas, S. N. (2020). Microplastics in the Edible and Inedible Tissues of Pelagic Fishes Sold for Human Consumption in Kerala, India. Environ. Pollut. 266, 115365. doi:10.1016/j.envpol.2020.115365

Di Lorenzo, F., De Castro, C., Silipo, A., and Molinaro, A. (2019). Lipopolysaccharide Structures of Gram-Negative Populations in the Gut Microbiota and Effects on Host Interactions. FEMS Microbiol. Rev. 43 (3), 257-272. doi:10.1093/femsre/fuz002

Ding, J., Sun, C., He, C., Li, J., Ju, P., and Li, F. (2021). Microplastics in Four Bivalve Species and Basis for Using Bivalves as Bioindicators of Microplastic Pollution. Science of the Total Environment, 782. doi:10.1016/j.scitotenv.2021.146830

Dong, C. D., Chen, C. W., Chen, Y. C., Chen, H. H., Lee, J. S., and Lin, C. H. (2020). Polystyrene Microplastic Particles: In Vitro Pulmonary Toxicity Assessment. J. Hazard. Mater. 385, 121575. doi:10.1016/j.jhazmat.2019.121575

Dowarah, K., Patchaiyappan, A., Thirunavukkarasu, C., Jayakumar, S., and Devipriya, S. P. (2020). Quantification of Microplastics Using Nile Red in Two Bivalve Species Perna Viridis and Meretrix Meretrix from Three Estuaries in Pondicherry, India and Microplastic Uptake by Local Communities through Bivalve Diet. Mar. Pollut. Bull. 153, 110982. doi:10.1016/ j.marpolbul.2020.110982

Dris, R., Gasperi, J., Saad, M., Mirande, C., and Tassin, B. (2016). Synthetic Fibers in Atmospheric Fallout: A Source of Microplastics in the Environment. Mar. Pollut. Bull. 104 (1-2), 290-293. doi:10.1016/j.marpolbul.2016.01.006

Dris, R., Gasperi, J., Mirande, C., Mandin, C., Guerrouache, M., Langlois, V., et al. (2017). A First Overview of Textile Fibers, Including Microplastics, in Indoor and Outdoor Environments. Environ. Pollut. 221, 453-458. doi:10.1016/ j.envpol.2016.12.013

Dris, R., Gasperi, J., Rocher, V., Saad, M., Renault, N., and Tassin, B. (2015). Microplastic Contamination in an Urban Area: A Case Study in Greater Paris. Environ. Chem. 12 (5), 592-599. doi:10.1071/en14167

Du, F., Cai, H., Zhang, Q., Chen, Q., and Shi, H. (2020). Microplastics in Take-Out Food Containers. J. Hazard. Mater. 399, 122969. doi:10.1016/ j.jhazmat.2020.122969

Duan, C., Fang, Y., Sun, J., Li, Z., Wang, Q., Bai, J., et al. (2020). Effects of Fast Food Packaging Plasticizers and Their Metabolites on Steroid Hormone Synthesis in H295R Cells, Sci. Total Environ., 726. 138500. doi:10.1016/j.scitotenv.2020.138500

Eerkes-Medrano, D., Thompson, R. C., and Aldridge, D. C. (2015). Microplastics in Freshwater Systems: A Review of the Emerging Threats, Identification of Knowledge Gaps and Prioritisation of Research Needs. Water Res. 75, 63-82. doi:10.1016/j.watres.2015.02.012

Efsa (2016). Presence of Microplastics and Nanoplastics in Food, with Particular Focus on Seafood. EFSA J. 14 (6).

Evariste, L., Barret, M., Mottier, A., Mouchet, F., Gauthier, L., and Pinelli, E. (2019). Gut Microbiota of Aquatic Organisms: A Key Endpoint for Ecotoxicological Studies. Environ. Pollut. 248, 989-999. doi:10.1016/ j.envpol.2019.02.101

Fackelmann, G., and Sommer, S. (2019). Microplastics and the Gut Microbiome: How Chronically Exposed Species May Suffer from Gut Dysbiosis. Mar. Pollut. Bull. 143, 193-203. doi:10.1016/j.marpolbul.2019.04.030

Fan, X., Gan, R., Liu, J., Xie, Y., Xu, D., Xiang, Y., et al. (2021). Adsorption and Desorption Behaviors of Antibiotics by Tire Wear Particles and Polyethylene 
Microplastics with or without Aging Processes, Sci. Total Environ., 771. 145451. doi:10.1016/j.scitotenv.2021.145451

Fang, C., Zheng, R., Chen, H., Hong, F., Lin, L., Lin, H., et al. (2019). Comparison of Microplastic Contamination in Fish and Bivalves from Two Major Cities in Fujian Province, China and the Implications for Human Health. Aquaculture 512, 734322. doi:10.1016/j.aquaculture.2019.734322

Fang, H., Fang, W., Cao, H., Luo, S., Cong, J., Liu, S., et al. (2019). Di-(2ethylhexyl)-phthalate Induces Apoptosis via the PPAR $\gamma / \mathrm{PTEN} / \mathrm{AKT}$ Pathway in Differentiated Human Embryonic Stem Cells. Food Chem. Toxicol. 131, 110552. doi:10.1016/j.fct.2019.05.060

Fouyet, S., Olivier, E., Leproux, P., Dutot, M., and Rat, P. (2021). Bisphenol A, Bisphenol F, and Bisphenol S: The Bad and the Ugly. Where Is the Good. Life (Basel) 11 (4). doi:10.3390/life11040314

Galloway, T. S. (2015). Micro- and Nano-Plastics and Human Health. Mar. Anthropogenic Litter, 343-366. doi:10.1007/978-3-319-16510-3 13

Ghosh, G. C., AkterIslam, S. M., Rashidul, M., Habib, A., Chakraborty, T. K., and Zaman, S. (2021). Microplastics Contamination in Commercial marine Fish from the Bay of Bengal. Reg. Stud. Mar. Sci. 44, 101728. doi:10.1016/ j.rsma.2021.101728

Goodman, K. E., Pineles, L., Magder, L. S., O'Hara, L. M., Pineles, B. L., Nadimpalli, G., et al. (2021). Exposure of Human Lung Cells to Polystyrene Microplastics Significantly Retards Cell Proliferation and Triggers Morphological Changes. Chem. Res. Toxicol. 34 (4), 1069-1081. doi:10.1021/acs.chemrestox.0c00486-

Hadibarata, T., Sathishkumar, P., Prasetia, H., HikmatPusfitasari, E. D., et al. (2021). Microplastic Contamination in the Skipjack Tuna (Euthynnus Affinis) Collected from Southern Coast of Java, Indonesia. Chemosphere 276, 130185. doi:10.1016/j.chemosphere.2021.130185

Hermabessiere, L., Dehaut, A., Paul-Pont, I., Lacroix, C., Jezequel, R., Soudant, P., et al. (2017). Occurrence and Effects of Plastic Additives on marine Environments and Organisms: A Review. Chemosphere 182, 781-793. doi:10.1016/j.chemosphere.2017.05.096

Hermabessiere, L., Paul-Pont, I., Cassone, A.-L., Himber, C., Receveur, J., Jezequel, R., et al. (2019). Microplastic Contamination and Pollutant Levels in Mussels and Cockles Collected along the Channel Coasts. Environ. Pollut. 250, 807-819. doi:10.1016/j.envpol.2019.04.051

Hollóczki, O., and Gehrke, S. (2019). Nanoplastics Can Change the Secondary Structure of Proteins. Sci. Rep. 9 (1), 16013. doi:10.1038/s41598-019-52495-w

Hollóczki, O., and Gehrke, S. (2020). Can Nanoplastics Alter Cell Membranes. ChemPhysChem 21 (1), 3. doi:10.1002/cphc.201901156

Horton, A. A., Walton, A., Spurgeon, D. J., Lahive, E., and Svendsen, C. (2017). Microplastics in Freshwater and Terrestrial Environments: Evaluating the Current Understanding to Identify the Knowledge Gaps and Future Research Priorities. Sci. Total Environ. 586, 127-141. doi:10.1016/j.scitotenv.2017.01.190

Huang, Y., Qing, X., Wang, W., Han, G., and Wang, J. (2020). Mini-review on Current Studies of Airborne Microplastics: Analytical Methods, Occurrence, Sources, Fate and Potential Risk to Human Beings. Trac Trends Anal. Chem. 125, 115821. doi:10.1016/j.trac.2020.115821

Huerta Lwanga, E., Mendoza Vega, J., Ku Quej, V., Chi, J. d. l. A., Sanchez del Cid, L., Chi, C., et al. (2017). Field Evidence for Transfer of Plastic Debris along a Terrestrial Food Chain. Sci. Rep. 7 (1), 14071. doi:10.1038/s41598-017-14588-2

Husøy, T., Andreassen, M., Hjertholm, H., Carlsen, M. H., Norberg, N., Sprong, C., et al. (2019). The Norwegian Biomonitoring Study from the EU Project EuroMix: Levels of Phenols and Phthalates in 24-hour Urine Samples and Exposure Sources from Food and Personal Care Products. Environ. Int. 132, 105103. doi:10.1016/j.envint.2019.105103

Hwang, J., Choi, D., Han, S., Jung, S. Y., Choi, J., and Hong, J. (2020). Potential Toxicity of Polystyrene Microplastic Particles. Sci. Rep. 10 (1), 7391. doi:10.1038/s41598-020-64464-9

Ivar Do Sul, J. A., and Costa, M. F. (2014). The Present and Future of Microplastic Pollution in the marine Environment. Environ. Pollut. 185, 352-364. doi:10.1016/j.envpol.2013.10.036

Kahn, L. G., Philippat, C., Nakayama, S. F., Slama, R., and Trasande, L. (2020). Endocrine-disrupting Chemicals: Implications for Human Health. Lancet Diabetes Endocrinol. 8 (8), 703-718. doi:10.1016/s2213-8587(20)30129-7

Kambia, N., Séverin, I., Farce, A., Dahbi, L., Dine, T., Moreau, E., et al. (2021). Comparative Effects of Di-(2-ethylhexyl)phthalate and Di-(2-ethylhexyl) terephthalate Metabolites on Thyroid Receptors: In Vitro and In Silico Studies. Metabolites 11 (2), 1-18. doi:10.3390/metabo11020094
Karami, A., Golieskardi, A., Choo, C. K., Larat, V., Karbalaei, S., and Salamatinia, B. (2018). Microplastic and Mesoplastic Contamination in Canned Sardines and Sprats. Sci. Total Environ. 612, 1380-1386. doi:10.1016/j.scitotenv.2017.09.005

Karlsson, T. M., Vethaak, A. D., Almroth, B. C., Ariese, F., van Velzen, M. Hassellöv, M., et al. (2017). Screening for Microplastics in Sediment, Water, marine Invertebrates and Fish: Method Development and Microplastic Accumulation. Mar. Pollut. Bull. 122 (1), 403-408. doi:10.1016/ j.marpolbul.2017.06.081

Kedzierski, M., Lechat, B., Sire, O., Le Maguer, G., Le Tilly, V., and Bruzaud, S. (2020). Microplastic Contamination of Packaged Meat: Occurrence and Associated Risks. Food Packaging and Shelf Life 24, 100489. doi:10.1016/ j.fpsl.2020.100489

Kim, H., Nam, K., Oh, S., Son, S., Jeon, D., Gye, M. C., et al. (2019). Toxicological Assessment of Phthalates and Their Alternatives Using Human Keratinocytes. Environ. Res. 175, 316-322. doi:10.1016/j.envres.2019.05.007

Knobloch, E., Ruffell, H., Aves, A., Pantos, O., Gaw, S., and Revell, L. E. (2021). Comparison of Deposition Sampling Methods to Collect Airborne Microplastics in Christchurch, New Zealand. Water Air Soil Pollut. 232 (4), 133. doi:10.1007/s11270-021-05080-9

Kosuth, M., Mason, S. A., and Wattenberg, E. V. (2018). Anthropogenic Contamination of Tap Water, Beer, and Sea Salt. PLoS ONE 13 (4), e0194970. doi:10.1371/journal.pone.0194970

Krasowska, A., and Sigler, K. (2014). How Microorganisms Use Hydrophobicity and what Does This Mean for Human Needs. Front Cel Infect Microbiol. 4 (112), 112. doi:10.3389/fcimb.2014.00112

Krivoshiev, B. V., Beemster, G. T. S., Sprangers, K., Cuypers, B., Laukens, K., Blust, R., et al. (2018). Toxicogenomics of the Flame Retardant Tris (2-butoxyethyl) Phosphate in HepG2 Cells Using RNA-Seq. Toxicol. Vitro 46, 178-188. doi:10.1016/j.tiv.2017.10.011

Laborda, F., Trujillo, C., and Lobinski, R. (2021). Analysis of Microplastics in Consumer Products by Single Particle-Inductively Coupled Plasma Mass Spectrometry Using the Carbon-13 Isotope. Talanta 221, 121486. doi:10.1016/j.talanta.2020.121486

Lang, M., Yu, X., Liu, J., Xia, T., Wang, T., Jia, H., et al. (2020). Fenton Aging Significantly Affects the Heavy Metal Adsorption Capacity of Polystyrene Microplastics. Sci. Total Environ. 722, 137762. doi:10.1016/ j.scitotenv.2020.137762

Lau, O. W., and Wong, S. K. (2000). Contamination in Food from Packaging Material. J. Chromatogr. A. 882 (1), 255-270. doi:10.1016/s0021-9673(00) 00356-3

Lehner, R., Wohlleben, W., Septiadi, D., Landsiedel, R., Petri-Fink, A., and RothenRutishauser, B. (2020). A Novel 3D Intestine Barrier Model to Study the Immune Response upon Exposure to Microplastics. Arch. Toxicol. 94 (7), 2463-2479. doi:10.1007/s00204-020-02750-1

Li, F., Yang, F., Li, D. K., Tian, Y., Miao, M., Zhang, Y., et al. (2020). Prenatal Bisphenol A Exposure, Fetal Thyroid Hormones and Neurobehavioral Development in Children at 2 and 4 years: A Prospective Cohort Study. Sci. Total Environ. 722, 137887. doi:10.1016/j.scitotenv.2020.137887

Li, J., Yang, D., Li, L., Jabeen, K., and Shi, H. (2015). Microplastics in Commercial Bivalves from China. Environ. Pollut. 207, 190-195. doi:10.1016/ j.envpol.2015.09.018

Li, Y., Chen, G., Xu, K., Huang, K., and Wang, J. (2021). Microplastics Environmental Effect and Risk Assessment on the Aquaculture Systems from south China. Int. J. Environ. Res. Public Health 18 (4), 1-14. doi:10.3390/ijerph18041869

Liu, C., Li, J., Zhang, Y., Wang, L., Deng, J., Gao, Y., et al. (2019). Widespread Distribution of PET and PC Microplastics in Dust in Urban China and Their Estimated Human Exposure. Environ. Int. 128, 116-124. doi:10.1016/ j.envint.2019.04.024

Liu, K., Wu, T., Wang, X., Song, Z., Zong, C., Wei, N., et al. (2019). Consistent Transport of Terrestrial Microplastics to the Ocean through Atmosphere. Environ. Sci. Technol. 53 (18), 10612-10619. doi:10.1021/acs.est.9b03427

Liu, L., Xu, K., Zhang, B., Ye, Y., Zhang, Q., and Jiang, W. (2021). Cellular Internalization and Release of Polystyrene Microplastics and Nanoplastics. Sci. Total Environ. 779, 146523. doi:10.1016/ j.scitotenv.2021.146523

Liu, S., Wu, X., Gu, W., Yu, J., and Wu, B. (2020). Influence of the Digestive Process on Intestinal Toxicity of Polystyrene Microplastics as Determined by In Vitro 
Caco-2 Models. Chemosphere 256, 127204. doi:10.1016/ j.chemosphere.2020.127204

Liu, W., Luo, D., Xia, W., Tao, Y., Wang, L., Yu, M., et al. (2021). Prenatal Exposure to Halogenated, Aryl, and Alkyl Organophosphate Esters and Child Neurodevelopment at Two Years of Age. J. Hazard. Mater. 408, 124856. doi:10.1016/j.jhazmat.2020.124856

Liu, X., Cai, Y., Wang, Y., Xu, S., Ji, K., and Choi, K. (2019). Effects of Tris(1,3-Dichloro-2-Propyl) Phosphate (TDCPP) and Triphenyl Phosphate (TPP) on Sex-dependent Alterations of Thyroid Hormones in Adult Zebrafish. Ecotoxicology Environ. Saf. 170, 25-32. doi:10.1016/ j.ecoenv.2018.11.058

Llorca, M., Ábalos, M., Vega-Herrera, A., Adrados, M. A., Abad, E., and Farré, M. (2020). Adsorption and Desorption Behaviour of Polychlorinated Biphenyls onto Microplastics' Surfaces in Water/sediment Systems. Toxics 8 (3). doi: $10.3390 /$ toxics 8030059

Llorca, M., Álvarez-Muñoz, D., Ábalos, M., Rodríguez-Mozaz, S., H.M.L.M. Santos, L., and M. León, V. (2020). Microplastics in Mediterranean Coastal Area: Toxicity and Impact for the Environment and Human Health. Trends Environ. Anal. Chem. 27, e00090. doi:10.1016/j.teac.2020.e00090

Llorca, M., Schirinzi, G., Martínez, M., Barceló, D., and Farré, M. (2018). Adsorption of Perfluoroalkyl Substances on Microplastics under Environmental Conditions. Environ. Pollut. 235, 680-691. doi:10.1016/ j.envpol.2017.12.075

Lu, L., Wan, Z., Luo, T., Fu, Z., and Jin, Y. (2018). Polystyrene Microplastics Induce Gut Microbiota Dysbiosis and Hepatic Lipid Metabolism Disorder in Mice. Sci. Total Environ. 631-632, 449-458. doi:10.1016/ j.scitotenv.2018.03.051

Lunov, O., Syrovets, T., Loos, C., Beil, J., Delacher, M., Tron, K., et al. (2011). Differential Uptake of Functionalized Polystyrene Nanoparticles by Human Macrophages and a Monocytic Cell Line. ACS nano 5, 1657-1669. doi:10.1021/ nn2000756

Ma, Y., Liu, H., Wu, J., Yuan, L., Wang, Y., Du, X., et al. (2019). The Adverse Health Effects of Bisphenol A and Related Toxicity Mechanisms. Environ. Res. 176, 108575. doi:10.1016/j.envres.2019.108575

Maddela, N. R., Venkateswarlu, K., Kakarla, D., and Megharaj, M. (2020). Inevitable Human Exposure to Emissions of Polybrominated Diphenyl Ethers: A Perspective on Potential Health Risks. Environ. Pollut. 266, 115240. doi:10.1016/j.envpol.2020.115240

Maffini, M. V., Rubin, B. S., Sonnenschein, C., and Soto, A. M. (2006). Endocrine Disruptors and Reproductive Health: The Case of Bisphenol-A. Mol. Cell Endocrinol. 254-255, 179-186. doi:10.1016/j.mce.2006.04.033

Makhdoumi, P., Amin, A. A., Karimi, H., Pirsaheb, M., Kim, H., and Hossini, H. (2021). Occurrence of Microplastic Particles in the Most Popular Iranian Bottled mineral Water Brands and an Assessment of Human Exposure. J. Water Process Eng. 39. doi:10.1016/j.jwpe.2020.101708

Marques, F., Vale, C., Rudnitskaya, A., Moreirinha, C., Costa, S. T., and Botelho, M. J. (2021). Major Characteristics of Microplastics in Mussels from the Portuguese Coast. Environ. Res. 197, 110993. doi:10.1016/j.envres.2021.110993

Mason, S. A., Welch, V. G., and Neratko, J. (2018). Synthetic Polymer Contamination in Bottled Water. Front. Chem. 6, 407. doi:10.3389/fchem.2018.00407

Meli, R., Monnolo, A., Annunziata, C., Pirozzi, C., and Ferrante, M. C. (2020). Oxidative Stress and BPA Toxicity: An Antioxidant Approach for Male and Female Reproductive Dysfunction. Antioxidants (Basel) 9 (5). doi:10.3390/ antiox9050405

Mintenig, S. M., Löder, M. G. J., Primpke, S., and Gerdts, G. (2019). Low Numbers of Microplastics Detected in Drinking Water from Ground Water Sources. Sci. Total Environ. 648, 631-635. doi:10.1016/j.scitotenv.2018.08.178

Mustieles, V., and Fernández, M. F. (2020). Bisphenol A Shapes Children's Brain and Behavior: Towards an Integrated Neurotoxicity Assessment Including Human Data. Environ. Health 19 (1), 66. doi:10.1186/s12940-020-00620-y

Mustieles, V., and Fernández, M. F. (2020). Bisphenol A Shapes Children's Brain and Behavior: towards an Integrated Neurotoxicity Assessment Including Human Data. Environ. Health 19 (1), 66. doi:10.1186/s12940-020-00620-y

Naji, A., Nuri, M., and Vethaak, A. D. (2018). Microplastics Contamination in Molluscs from the Northern Part of the Persian Gulf. Environ. Pollut. 235, 113-120. doi:10.1016/j.envpol.2017.12.046

Nalbone, L., Cincotta, F., Giarratana, F., Ziino, G., and Panebianco, A. (2021). Microplastics in Fresh and Processed Mussels Sampled from Fish Shops and
Large Retail Chains in Italy. Food Control 125, 108003. doi:10.1016/ j.foodcont.2021.108003

Oliveri Conti, G., Ferrante, M., Banni, M., Favara, C., Nicolosi, I., Cristaldi, A., et al. (2020). Micro- and Nano-Plastics in Edible Fruit and Vegetables. The First Diet Risks Assessment for the General Population. Environ. Res. 187, 109677. doi:10.1016/j.envres.2020.109677

Ouyang, F., Zhang, G. H., Du, K., Shen, L., Ma, R., Wang, X., et al. (2020). Maternal Prenatal Urinary Bisphenol A Level and Child Cardio-Metabolic Risk Factors: A Prospective Cohort Study. Environ. Pollut. 265, 115008. doi:10.1016/ j.envpol.2020.115008

Oßmann, B. E. (2021). Microplastics in Drinking Water? Present State of Knowledge and Open Questions. Curr. Opin. Food Sci. 41, 44-51. doi:10.1016/j.cofs.2021.02.011

Pelch, K. E., Reade, A., Wolffe, T. A. M., and Kwiatkowski, C. F. (2019). PFAS Health Effects Database: Protocol for a Systematic Evidence Map. Environ. Int. 130, 104851. doi:10.1016/j.envint.2019.05.045

Pérez-Albaladejo, E., Fernandes, D., Lacorte, S., and Porte, C. (2017). Comparative Toxicity, Oxidative Stress and Endocrine Disruption Potential of Plasticizers in JEG-3 Human Placental Cells. Toxicol. Vitro 38, 41-48. doi:10.1016/ j.tiv.2016.11.003

Peshdary, V., Hobbs, C. A., Maynor, T., Shepard, K., Gagné, R., Williams, A., et al. (2021). Transcriptomic Pathway and Benchmark Dose Analysis of Bisphenol A, Bisphenol S, Bisphenol F, and 3,3',5,5'-Tetrabromobisphenol A in H9 Human Embryonic Stem Cells. Toxicol. Vitro 72, 105097. doi:10.1016/j.tiv.2021.105097

Plastics the Facts (2019). An Analysis of European Plastics Production, Demand and Waste Data. An Analysis of European Plastics Production, Demand and Waste Data.

Powell, J. J., Faria, N., Thomas-McKay, E., and Pele, L. C. (2010). Origin and Fate of Dietary Nanoparticles and Microparticles in the Gastrointestinal Tract. J. Autoimmun. 34 (3), J226-J233. doi:10.1016/j.jaut.2009.11.006

Prata, J. C., da Costa, J. P., Lopes, I., Duarte, A. C., and Rocha-Santos, T. (2020). Environmental Exposure to Microplastics: An Overview on Possible Human Health Effects. Sci. Total Environ. 702, 134455. doi:10.1016/ j.scitotenv.2019.134455

Pratiwi, A., Syafei, A. D., Assomadi, A. F., Boedisantoso, R., and Hermana, J. (2020). Microplastic Characterization Based on the Number of Occupants. AIP Conf. Proc. doi:10.1063/5.0030816

Puckowski, A., Cwięk, W., Mioduszewska, K., Stepnowski, P., and BiałkBielińska, A. (2021). Sorption of Pharmaceuticals on the Surface of Microplastics. Chemosphere 263, 127976. doi:10.1016/ j.chemosphere.2020.127976

Rafael-Vázquez, L., García-Trejo, S., Aztatzi-Aguilar, O. G., Bazán-Perkins, B., and Quintanilla-Vega, B. (2018). Exposure to Diethylhexyl Phthalate (DEHP) and Monoethylhexyl Phthalate (MEHP) Promotes the Loss of Alveolar Epithelial Phenotype of A549 Cells. Toxicol. Lett. 294, 135-144. doi:10.1016/ j.toxlet.2018.05.012

Reddam, A., Mitchell, C. A., Dasgupta, S., Kirkwood, J. S., Vollaro, A., Hur, M. et al. (2019). MRNA-sequencing Identifies Liver as a Potential Target Organ for Triphenyl Phosphate in Embryonic Zebrafish. Toxicol. Sci. 172 (1), 51-62. doi:10.1093/toxsci/kfz169

Renzi, M., and Blašković, A. (2018). Litter \& Microplastics Features in Table Salts from marine Origin: Italian versus Croatian Brands. Mar. Pollut. Bull. 135, 62-68. doi:10.1016/j.marpolbul.2018.06.065

Revel, M., Châtel, A., and Mouneyrac, C. (2018). Micro(nano)plastics: A Threat to Human Health. Curr. Opin. Environ. Sci. Health 1, 17-23. doi:10.1016/ j.coesh.2017.10.003

Rist, S., Steensgaard, I. M., Guven, O., Nielsen, T. G., Jensen, L. H., Møller, L. F., et al. (2019). The Fate of Microplastics during Uptake and Depuration Phases in a Blue Mussel Exposure System. Environ. Toxicol. Chem. 38 (1), 99-105. doi:10.1002/etc. 4285

Rochester, J. R. (2013). Bisphenol A and Human Health: A Review of the Literature. Reprod. Toxicol. 42, 132-155. doi:10.1016/j.reprotox.2013.08.008

Rogers, K. L., Carreres-Calabuig, J. A., Gorokhova, E., and Posth, N. R. (2020). Micro-by-micro Interactions: How Microorganisms Influence the Fate of marine Microplastics. Limnol Oceanogr 5 (1), 18-36. doi:10.1002/ lol2.10136

Santillo, D., Miller, K., and Johnston, P. (2017). Microplastics as Contaminants in Commercially Important Seafood Species. Integr. Environ. Assess. Manag. 13 (3), 516-521. doi:10.1002/ieam.1909 
Sapea, S. A. f. P. b. E. A. (2019). A Scientific Perspective On Microplastics In Nature And Society. A Scientific Perspective on Microplastics in Nature and Society.

Schirinzi, G. F., Llorca, M., Seró, R., Moyano, E., Barceló, D., Abad, E., et al. (2019). Trace Analysis of Polystyrene Microplastics in Natural Waters. Chemosphere 236, 124321. doi:10.1016/j.chemosphere.2019.07.052

Schirinzi, G. F., Pedà, C., Battaglia, P., Laface, F., Galli, M., Baini, M., et al. (2020). A New Digestion Approach for the Extraction of Microplastics from Gastrointestinal Tracts (GITs) of the Common Dolphinfish (Coryphaena hippurus) from the Western Mediterranean Sea. J. Hazard. Mater. 397, 122794. doi:10.1016/j.jhazmat.2020.122794

Schirinzi, G. F., Pérez-Pomeda, I., Sanchís, J., Rossini, C., Farré, M., and Barceló, D. (2017). Cytotoxic Effects of Commonly Used Nanomaterials and Microplastics on Cerebral and Epithelial Human Cells. Environ. Res. 159, 579-587. doi:10.1016/j.envres.2017.08.043

Schymanski, D., Goldbeck, C., Humpf, H.-U., and Fürst, P. (2018). Analysis of Microplastics in Water by Micro-raman Spectroscopy: Release of Plastic Particles from Different Packaging into mineral Water. Water Res. 129, 154-162. doi:10.1016/j.watres.2017.11.011

Sedha, S., Lee, H., Singh, S., Kumar, S., Jain, S., Ahmad, A., et al. (2021). Reproductive Toxic Potential of Phthalate Compounds - State of Art Review. Pharmacol. Res. 167, 105536. doi:10.1016/j.phrs.2021.105536

Selvam, S., Manisha, A., Venkatramanan, S., Chung, S. Y., Paramasivam, C. R., and Singaraja, C. (2020). Microplastic Presence in Commercial marine Sea Salts: A Baseline Study along Tuticorin Coastal Salt pan Stations, Gulf of Mannar, South India. Mar. Pollut. Bull. 150, 110675. doi:10.1016/ j.marpolbul.2019.110675

Seth, C. K., and Shriwastav, A. (2018). Contamination of Indian Sea Salts with Microplastics and a Potential Prevention Strategy. Environ. Sci. Pollut. Res. 25 (30), 30122-30131. doi:10.1007/s11356-018-3028-5

Shi, Q., Tang, J., Wang, L., Liu, R., and Giesy, J. P. (2021). Combined Cytotoxicity of Polystyrene Nanoplastics and Phthalate Esters on Human Lung Epithelial A549 Cells and its Mechanism. Ecotoxicol Environ. Saf. 213, 112041. doi:10.1016/ j.ecoenv.2021.112041

Shruti, V. C., Pérez-Guevara, F., Elizalde-Martínez, I., and Kutralam-Muniasamy, G. (2020). First Study of its Kind on the Microplastic Contamination of Soft Drinks, Cold tea and Energy Drinks - Future Research and Environmental Considerations, Sci. Total Environ., 726. 138580. doi:10.1016/ j.scitotenv.2020.138580

Shruti, V. C., Pérez-Guevara, F., and Kutralam-Muniasamy, G. (2020). Metro Station Free Drinking Water fountain- A Potential "microplastics Hotspot" for Human Consumption. Environ. Pollut. 261, 114227. doi:10.1016/ j.envpol.2020.114227

Sicińska, P. (2018). Di-n-butyl Phthalate, Butylbenzyl Phthalate and Their Metabolites Induce Haemolysis and Eryptosis in Human Erythrocytes. Chemosphere 203, 44-53. doi:10.1016/j.chemosphere.2018.03.161

Smith, M., Love, D. C., Rochman, C. M., and Neff, R. A. (2018). Microplastics in Seafood and the Implications for Human Health. Curr. Envir Health Rpt 5 (3), 375-386. doi:10.1007/s40572-018-0206-z

Soltani, N. S., Taylor, M. P., and Wilson, S. P. (2021). Quantification and Exposure Assessment of Microplastics in Australian Indoor House Dust. Environ. Pollut. 283, 117064. doi:10.1016/j.envpol.2021.117064

Stock, V., Laurisch, C., Franke, J., Dönmez, M. H., Voss, L., Böhmert, L., et al. (2021). Uptake and Cellular Effects of PE, PP, PET and PVC Microplastic Particles. Toxicol. Vitro 70, 105021. doi:10.1016/j.tiv.2020.105021

Su, L., Deng, H., Li, B., Chen, Q., Pettigrove, V., Wu, C., et al. (2019). The Occurrence of Microplastic in Specific Organs in Commercially Caught Fishes from Coast and Estuary Area of east China. J. Hazard. Mater. 365, 716-724. doi:10.1016/j.jhazmat.2018.11.024

Teng, J., Wang, Q., Ran, W., Wu, D., Liu, Y., Sun, S., et al. (2019). Microplastic in Cultured Oysters from Different Coastal Areas of China. Sci. Total Environ. 653, 1282-1292. doi:10.1016/ j.scitotenv.2018.11.057

Tickner, J. A., Schettler, T., Guidotti, T., McCally, M., and Rossi, M. (2001). Health Risks Posed by Use of Di-2-ethylhexyl Phthalate (DEHP) in PVC Medical Devices: A Critical Review. Am. J. Ind. Med. 39 (1), 100-111. doi:10.1002/10970274(200101)39:1<100:aid-ajim10>3.0.co;2-q
Tong, H., Jiang, Q., Hu, X., and Zhong, X. (2020). Occurrence and Identification of Microplastics in Tap Water from China. Chemosphere 252, 126493. doi:10.1016/j.chemosphere.2020.126493

Torres, F. G., Dioses-Salinas, D. C., Pizarro-Ortega, C. I., and De-la-Torre, G. E. (2021). Sorption of Chemical Contaminants on Degradable and Nondegradable Microplastics: Recent Progress and Research Trends. Sci. Total Environ. 757, 143875. doi:10.1016/j.scitotenv.2020.143875

Van Cauwenberghe, L., Claessens, M., Vandegehuchte, M. B., and Janssen, C. R. (2015). Microplastics Are Taken up by Mussels (Mytilus edulis) and Lugworms (Arenicola marina) Living in Natural Habitats. Environ. Pollut. 199, 10-17. doi:10.1016/j.envpol.2015.01.008

Van Cauwenberghe, L., and Janssen, C. R. (2014). Microplastics in Bivalves Cultured for Human Consumption. Environ. Pollut. 193, 65-70. doi:10.1016/j.envpol.2014.06.010

Vasconcelos, A. L., Silva, M. J., and Louro, H. (2019). In Vitro exposure to the NextGeneration Plasticizer Diisononyl Cyclohexane-1,2-Dicarboxylate (DINCH): Cytotoxicity and Genotoxicity Assessment in Human Cells. J. Toxicol. Environ. Health A 82 (9), 526-536. doi:10.1080/15287394.2019.1634376

Vianello, A., Jensen, R. L., Liu, L., and Vollertsen, J. (2019). Simulating Human Exposure to Indoor Airborne Microplastics Using a Breathing Thermal Manikin. Sci. Rep. 9 (1), 8670. doi:10.1038/s41598-01945054-w

Wang, C., Chen, H., Li, H., Yu, J., Wang, X., and Liu, Y. (2020). Review of Emerging Contaminant Tris(1,3-Dichloro-2-Propyl)phosphate: Environmental Occurrence, Exposure, and Risks to Organisms and Human Health. Environ. Int. 143, 105946. doi:10.1016/j.envint.2020.105946

Wang, L., Wang, Y., Xu, M., Ma, J., Zhang, S., Liu, S., et al. (2021). Enhanced Hepatic Cytotoxicity of Chemically Transformed Polystyrene Microplastics by Simulated Gastric Fluid. J. Hazard. Mater. 410, 124536. doi:10.1016/ j.jhazmat.2020.124536

Wang, X., Li, C., Liu, K., Zhu, L., Song, Z., and Li, D. (2020). Atmospheric Microplastic over the South China Sea and East Indian Ocean: Abundance, Distribution and Source. J. Hazard. Mater. 389, 121846. doi:10.1016/ j.jhazmat.2019.121846

Wang, Y., Xu, L., Peng, L., Fang, C., Qin, Q., Lv, X., et al. (2021). Polybrominated Diphenyl Ethers Quinone-Induced Intracellular Protein Oxidative Damage Triggers Ubiquitin-Proteasome and Autophagy-Lysosomal System Activation in LO2 Cells. Chemosphere 275, 130034. doi:10.1016/ j.chemosphere.2021.130034

Who, M. (2019). Drinking Water. Microplastics in Drinking Water.

Wright, S. L., and Kelly, F. J. (2017). Plastic and Human Health: A Micro Issue. Environ. Sci. Technol. 51 (12), 6634-6647. doi:10.1021/ acs.est.7b00423

Wu, B., Wu, X., Liu, S., Wang, Z., and Chen, L. (2019). Size-dependent Effects of Polystyrene Microplastics on Cytotoxicity and Efflux Pump Inhibition in Human Caco-2 cells. Chemosphere 221, 333-341. doi:10.1016/ j.chemosphere.2019.01.056

Wu, S., Wu, M., Tian, D., Qiu, L., and Li, T. (2020). Effects of Polystyrene Microbeads on Cytotoxicity and Transcriptomic Profiles in Human Caco-2 Cells. Environ. Toxicol. 35 (4), 495-506. doi:10.1002/tox.22885

Xiong, H., Huang, Y., Mao, Y., Liu, C., and Wang, J. (2021). Inhibition in Growth and Cardiotoxicity of Tris (2-butoxyethyl) Phosphate through DownRegulating Wnt Signaling Pathway in Early Developmental Stage of Zebrafish (Danio rerio), Ecotoxicol Environ. Saf., 208. 111431. doi:10.1016/ j.ecoenv.2020.111431

Xu, M., Halimu, G., Zhang, Q., Song, Y., Fu, X., Li, Y., et al. (2019). Internalization and Toxicity: A Preliminary Study of Effects of Nanoplastic Particles on Human Lung Epithelial Cell, Sci. Total Environ., 694. 133794. doi:10.1016/ j.scitotenv.2019.133794

Yan, Z., Jin, X., Liu, D., Hong, Y., Liao, W., Feng, C., et al. (2021). The Potential Connections of Adverse Outcome Pathways with the hazard Identifications of Typical Organophosphate Esters Based on Toxicity Mechanisms. Chemosphere 266, 128989. doi:10.1016/j.chemosphere.2020.128989

Zhang, L., Xie, Y., Zhong, S., Liu, J., Qin, Y., and Gao, P. (2021). Microplastics in Freshwater and Wild Fishes from Lijiang River in Guangxi, Southwest China. Sci. Total Environ. 755, 142428. doi:10.1016/ j.scitotenv.2020.142428 
Zhang, M., Li, J., Ding, H., Ding, J., Jiang, F., Ding, N. X., et al. (2020). Distribution Characteristics and Influencing Factors of Microplastics in Urban Tap Water and Water Sources in Qingdao, China. Anal. Lett. 53 (8), 1312-1327. doi:10.1080/00032719.2019.1705476

Zhang, Q., Zhao, Y., Du, F., Cai, H., Wang, G., and Shi, H. (2020). Microplastic Fallout in Different Indoor Environments. Environ. Sci. Technol. 54 (11), 6530-6539. doi:10.1021/acs.est.0c00087

Zhou, Q., Tian, C., and Luo, Y. (2017). Various Forms and Deposition Fluxes of Microplastics Identified in the Coastal Urban Atmosphere. Chin. Sci. Bull. 62, 3902-3909. doi:10.1360/n972017-00956

Zhu, L., Huang, X., Li, Z., Cao, G., Zhu, X., She, S., et al. (2021). Evaluation of Hepatotoxicity Induced by 2-ethylhexyldiphenyl Phosphate Based on Transcriptomics and its Potential Metabolism Pathway in Human Hepatocytes. J. Hazard. Mater. 413, 125281. doi:10.1016/ j.jhazmat.2021.125281

Zimmermann, L., Dierkes, G., Ternes, T. A., Völker, C., and Wagner, M. (2019). Benchmarking the In Vitro Toxicity and Chemical Composition of Plastic Consumer Products. Environ. Sci. Technol. 53 (19), 11467-11477. doi:10.1021/ acs.est.9b02293

Zitouni, N., Bousserrhine, N., Belbekhouche, S., Missawi, O., Alphonse, V., Boughatass, I., et al. (2020). First Report on the Presence of Small
Microplastics $(\leq 3 \mu \mathrm{m})$ in Tissue of the Commercial Fish Serranus Scriba (Linnaeus. 1758) from Tunisian Coasts and Associated Cellular Alterations. Environ. Pollut. 263, 114576. doi:10.1016/ j.envpol.2020.114576

Conflict of Interest: The authors declare that the research was conducted in the absence of any commercial or financial relationships that could be construed as a potential conflict of interest.

Publisher's Note: All claims expressed in this article are solely those of the authors and do not necessarily represent those of their affiliated organizations, or those of the publisher, the editors and the reviewers. Any product that may be evaluated in this article, or claim that may be made by its manufacturer, is not guaranteed or endorsed by the publisher.

Copyright (C) 2021 Llorca and Farré. This is an open-access article distributed under the terms of the Creative Commons Attribution License (CC BY). The use, distribution or reproduction in other forums is permitted, provided the original author(s) and the copyright owner(s) are credited and that the original publication in this journal is cited, in accordance with accepted academic practice. No use, distribution or reproduction is permitted which does not comply with these terms. 